\title{
An updated introduction to electroencephalogram-based brain monitoring during intended general anesthesia
}

\author{
Darren F. Hight, PhD $\cdot$ Heiko A. Kaiser, MD $\cdot$ Jamie W. Sleigh, MBChB $\cdot$ Michael S. Avidan, MBBCh $\square$
}

Received: 3 March 2019/Revised: 25 July 2019/Accepted: 13 July 2020

(C) Canadian Anesthesiologists' Society 2020, corrected publication 2020

\begin{abstract}
The electroencephalogram (EEG) provides a reliable reflection of the brain's electrical state, so it can reassure us that the anesthetic agents are actually reaching the patient's brain, and are having the desired effect. In most patients, the EEG changes somewhat predictably in response to propofol and volatile agents, so a frontal EEG channel can guide avoidance of insufficient and excessive administration of general anesthesia. Persistent alphaspindles (around $10 \mathrm{~Hz}$ ) phase-amplitude coupled with slow delta waves (around $1 \mathrm{~Hz}$ ) are commonly seen during an "appropriate hypnotic state of general anesthesia". Such patterns can be appreciated from the EEG waveform or from the spectrogram (a colour-coded display of how the power in the various EEG frequencies changes with time). Nevertheless, there are exceptions to this. For example, administration of ketamine and nitrous oxide is generally not associated with the aforementioned alphaspindle coupled with delta wave pattern. Also, some patients, including older adults and those with neurodegenerative disorders, are less predisposed to generate a strong electroencephalographic "alphaspindle" pattern during general anesthesia. There might
\end{abstract}

D. F. Hight, $\mathrm{PhD}$ - H. A. Kaiser, MD

Department of Anaesthesiology and Pain Medicine, Bern University Hospital, University of Bern, Bern, Switzerland

J. W. Sleigh, MBChB

Department of Anaesthesiology, University of Auckland,

Auckland, New Zealand

M. S. Avidan, MBBCh $(\square)$

Department of Anesthesiology, Washington University School of Medicine, 660 South Euclid Avenue, Campus Box 8054, St. Louis, MO, USA

e-mail: avidanm@wustl.edu also be some rare instances when the frontal EEG shows a pattern suggestive of general anesthesia, while the patient has some awareness and is able to follow simple commands, albeit this is typically without obvious distress or memory formation. Thus, the frontal EEG alone, as currently analyzed, is an imperfect but clinically useful mirror, and more scientific insights will be needed before we can claim to have a reliable readout of brain "function" during general anesthesia.

Objectives of the Continuing Professional Development module:

After reading this module, the reader should be able to:

1) Formulate basic concepts of the typical electroencephalogram (EEG) changes accompanying general anesthesia with volatile anesthetics or propofol.

2) Differentiate excessive, adequate, and possibly insufficient "hypnosis" during intended general anesthesia, based on the EEG.

3) Apply information gained from the raw EEG or its density spectral array/spectrogram to guide administration of volatile or intravenous anesthetic agents.

4) Recognize some less common situations in which frontal EEG features appear to be discordant with brain state, based on patient behaviour.

Considering that the brain is humankind's most distinctive organ, it is surprising that it is the only vital organ whose function we do not routinely monitor in the 
operating room or the intensive care unit. The most plausible explanation is that, unlike with the kidney, heart, lungs or liver, we have not had the ability to easily monitor aspects of brain function during pharmacologically induced unconsciousness. In clinical medicine, the only way we can reliably monitor certain brain functions is when people are conscious; through their interactions with the environment, we can generally ascertain how well their brains are working. Given that consciousness is dependent on neuronal activity, and that general anesthetics have their disruptive effect at the neuronal level, a measure of neuronal activity when responsiveness and memory are disrupted should be of deep interest to every anesthesiologist. The electroencephalogram (EEG) is an easily obtained measure of neural activity, quantifying noninvasively from the scalp the summed, synchronous electrical activity of millions of neurons in the cerebral cortex.

In 1937, Gibbs, Gibbs, and Lennox recommended that anesthesiologists should routinely use the EEG to monitor the "brain dysfunction" engendered by general anesthesia. ${ }^{1}$ Nevertheless, it is only in recent decades that anesthesiologists have begun to routinely use this information to help guide the conduct of general anesthesia. The purpose of this review is to summarize the current state of knowledge regarding the use of the EEG during intended general anesthesia. The first section will briefly focus on the well-known archetypal changes in the frontal EEG with increasing anesthetic concentration, whereas the second section will provide scenarios where the EEG may not always change in a typical manner with increasing or decreasing anesthetic concentration. A final section will cover unsolved problems and future directions for EEG monitoring during general anesthesia. Note that this review will not address in any detail the processed, proprietary, EEG indices, but rather focus on the unprocessed EEG signal displayed by all monitors.

Three views of the EEG: amplitude over time (raw EEG), power over frequency (power spectrum), and power per frequency over time (the spectrogram)

Three classic ways of viewing the EEG that will be used in this article. The first is to view the fluctuations in EEG amplitude (measured in microvolts, $\mu \mathrm{V}$ ) as they occur over time. This is referred to as the raw EEG and is shown in Fig. 1. From this perspective (also called the time domain) one can see the EEG waveform morphology and visually estimate the frequency of an oscillation by counting the number of oscillation peaks per second (see also Fig. 3). Nonetheless, because a typical EEG during general anesthesia consists of a mix of oscillations with different amplitudes and frequencies, a second view-the power spectrum-is helpful. To create a power spectrum (also called the frequency domain), a section of EEG is transformed using the Fast Fourier Transform, which calculates a power value (amplitude squared $[\mu \mathrm{V}]^{2}$ for each frequency bin. As the power spectrum quantifies the degree that oscillations at each frequency contribute to the EEG section, it can sometimes reveal frequency content that may not be seen by eye in the time domain. The third view of the EEG, the spectrogram, displays how the power at each frequency in the EEG changes over time, i.e., over successive sections of EEG. To create this perspective, the power values in the power spectrum are colour coded, where high power is red and low power is blue (see Fig. 2 row 2). A moving window is then run over the EEG producing successive power spectra, which are then viewed from "above", where frequency is on the y-axis, time is on the $\mathrm{x}$-axis, and power is shown as a colour scale. The advantage of this perspective is that it can show subtle changes in the frequency content of the EEG over long periods (i.e., hours).

Classic changes in the frontal EEG with increasing anesthetic concentrations

When a patient is given increasing doses of gammaaminobutyric acid (GABA)ergic anesthetics such as etherbased volatile agents or propofol (see for example references ${ }^{2}$ and, ${ }^{3}$ the vast majority of patients show predictable changes in the frontal EEG; although there is both inter- and intra-patient variability. Three classic oscillatory patterns are described with "typical" general anesthesia. These characteristic oscillations are slow waves $(<1 \mathrm{~Hz})$, delta waves $(1-4 \mathrm{~Hz})$, and continuous spindles/ alpha activity $(8-12 \mathrm{~Hz})$. In this article we have chosen the phrase "alpha-spindles" to denote oscillatory activity during general anesthesia that falls largely within the classic alpha frequency range of 8-12 Hz. Nonetheless, we note two caveats: firstly, that these same oscillations can sometimes be faster or slower than classic alpha (e.g., they slow with increasing age, and also with increasing volatile anesthetic concentration), and secondly, that they are dissimilar to the sleep spindle of stage N2 sleep in that they are more continuous, and are also frontally located (see Fig. 1). These oscillations are thought to be generated by the thalamocortical system acting as a complex network. ${ }^{4}$ The spindles are thought to result from repetitive alternating spike and burst patterns in thalamic reticular neurons producing rhythmic inhibitory postsynaptic potentials in thalamocortical neurons. Delta oscillations during anesthesia might represent a more hyperpolarized level of thalamocortical neuron membrane potentials than when spindles alone are generated. ${ }^{5}$ When thalamocortical neurons are hyperpolarized, environmental 

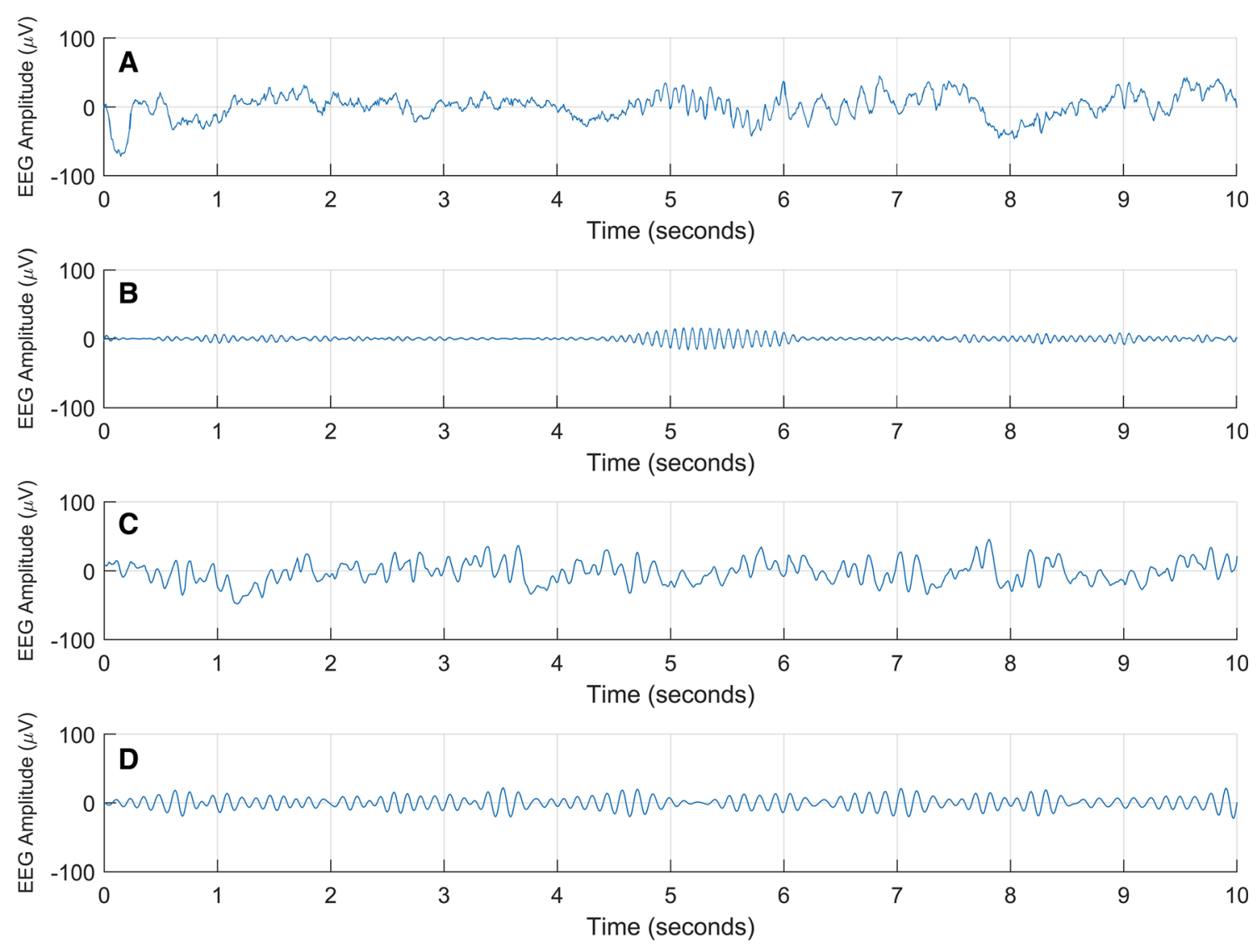

Fig. 1 Electroencephalogram (EEG) examples during sleep and general anesthesia. (A) A classic sleep-spindle during natural sleep (from around 4.5 until six seconds) with a frequency of near to $12 \mathrm{~Hz}$. (B) Bandpass filtered EEG (where oscillations apart from between 10 and $14 \mathrm{~Hz}$ are attenuated) of the signal in (A) to show the increasing and then decreasing amplitude of the sleep spindle. The sleep EEG recording was taken from the Sleep-EDF Database. ${ }^{7}$ (C) EEG during general anesthesia. (D) The signal in $\mathrm{C}$ bandpass filtered $(6-10 \mathrm{~Hz})$ to show the quasi-persistent alpha-spindle oscillation

inputs, such as noxious surgical stimuli, are usually partially curtailed in their transmission via the thalamus to the cortex. Thalamic reticular neurons (surrounding the thalamus), intra-thalamic neurons, and cortical neurons are all probably capable of generating low-frequency rhythms associated with general anesthesia. ${ }^{6}$

At anesthetic concentrations causing mild sedation, the frontal EEG waveform is typically initially dominated by slow beta activity, showing activity around $12-20 \mathrm{~Hz}$. The patient might display signs of paradoxical excitation during this period. As the patient loses responsiveness with increasing drug concentrations, slowing of the alpha frequency band (8-12 Hz) is usually seen (Fig. 2, parts B and C) ${ }^{8,9}$ When a person is awake and relaxed with eyes closed, a posterior dominant (alpha) rhythm is typically apparent in the EEG over occipital and parietal regions.
Exemples de tracés sur l'électroencéphalogramme (EEG) pendant le sommeil et l'anesthésie générale. (A) Un fuseau du sommeil typique pendant le sommeil naturel (d'environ 4,5 jusqu'à six secondes) à une fréquence proche de $12 \mathrm{~Hz}$. (B) EEG filtré par bande passante (où les oscillations en dehors de 10 à $14 \mathrm{~Hz}$ sont atténuées) du signal en (A) pour montrer l'amplitude croissante puis décroissante du fuseau du sommeil. L'enregistrement de l'EEG du sommeil a été pris de la Base de données Sleep-EDF. ${ }^{7}$ (C) EEG pendant une anesthésie générale. (D) Le signal de $C$ filtré par bande passante $(6-10 \mathrm{~Hz})$ afin de montrer l'oscillation quasi-persistante du fuseau alpha

During loss of responsiveness (induction of anesthesia), this dominant power in the alpha frequency band shifts from occipital and parietal areas to frontal areas of the brain, a phenomenon known as anteriorization, ${ }^{10}$ making frontal EEG monitoring during anesthesia feasible and convenient.

After loss of responsiveness, a slower oscillation (1-4 $\mathrm{Hz}$ ) will also appear in the EEG, often named slow-wave or delta activity (see Fig. $2 \mathrm{C}$ and Fig. 3). Further increase in hypnotic dose leads to periods of EEG suppression (i.e., low amplitude, often less than $5 \mu \mathrm{V}$ ) interspersed with bursts of high-amplitude $(>20 \mu \mathrm{V})$ activity, referred to as burst suppression (Fig. 2, column D, row 1), before finally leading to a continuously suppressed EEG (a complete absence of any visible oscillations) at high anesthetic concentrations. In the power spectrum (Fig. 2, column D, 
A
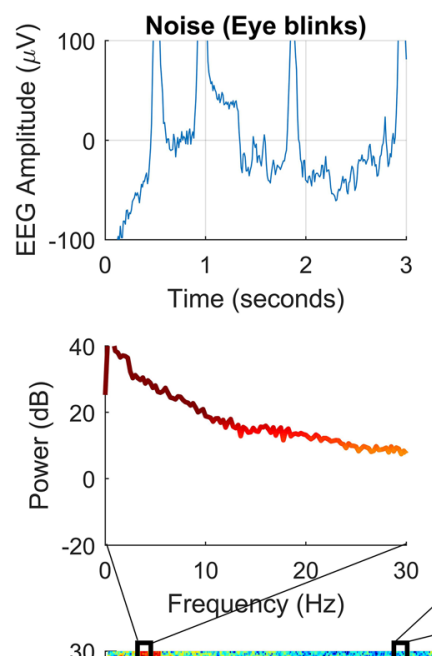

B
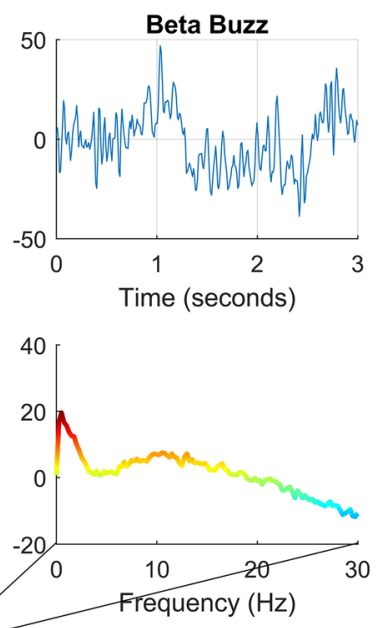

C
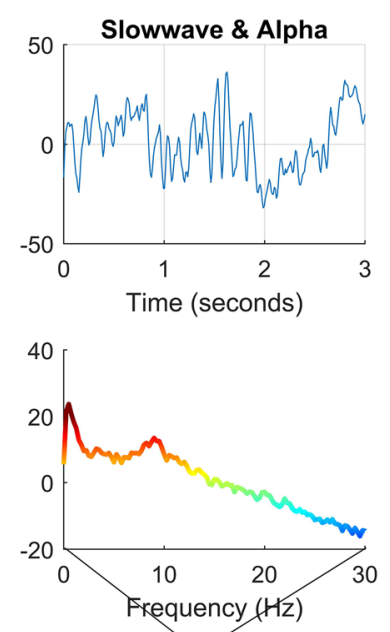
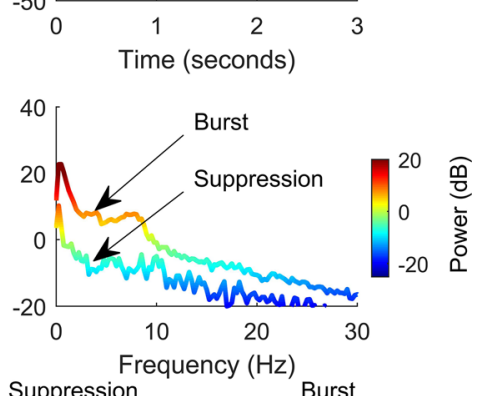
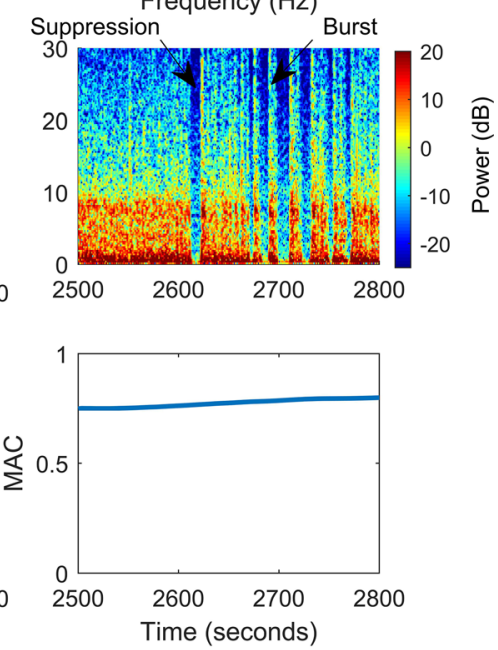

Fig. 2 Classic frontal electroencephalogram (EEG) responses to increasing anesthetic concentration (row 4), showing example raw EEG (row 1), power spectra (row 2), spectral changes over time (density spectral array, or spectrogram, row 3), and volatile anesthetic concentration (in minimum alveolar concentration, row 4). Section A depicts noise, such as eye blinks while awake, where large amplitude EEG deflections lead to high power over a wide frequency range. Section B shows EEG oscillations within the beta range $(12-30 \mathrm{~Hz})$, transitioning to a slow-wave with alpha-spindles EEG shown in section C. Section D shows burst suppression; the abrupt loss of power occurring during an ongoing slow-wave and alpha-spindles EEG is typical for isoflurane anesthesia (as well as other potent volatile anesthetic agents)

row 2), bursts show up as periods of high power over all frequencies, and periods of suppression as low power over all frequencies. In the spectrogram (Fig. 2, column D, row 3 ), the periods of suppression show up as sharply defined perpendicular stripes of colder colours (blue).

These classic EEG responses to increasing anesthetic concentrations have been illustrated in many articles over the decades. Noteworthy and comprehensive early articles
Réponses classiques sur un électroencéphalogramme (EEG) frontal à une concentration anesthésique croissante (rangée 4), montrant un exemple d'EEG brut (rangée 1), de spectres de puissance (rangée 2), de changements spectraux dans le temps (matrice de densité spectrale, ou spectrogramme, rangée 3), et de concentration de l'anesthésique volatil (en concentration alvéolaire minimale, rangée 4). La section A décrit du bruit, tels que des clignements des yeux en état d'éveil, lorsque de vaste déflections de l'amplitude de l'EEG entraînent une puissance élevée sur une vaste bande de fréquences. La section $\mathrm{B}$ montre les oscillations de l'EEG dans la bande bêta $(12-30 \mathrm{~Hz})$, devenant un EEG à ondes lentes avec des fuseaux alpha tel qu'exemplifié dans la section C. La section D montre des bouffées suppressives (burst suppression); la perte abrupte de puissance survenant pendant un EEG continu d'ondes lentes et de fuseaux alpha est typique d'une anesthésie à l'isoflurane (ainsi qu'avec d'autres agents anesthésiques volatils puissants)

include those by Rampil ${ }^{11}$ and Jameson and Sloan. ${ }^{12}$ Brown et al. ${ }^{13}$ later focus on the arousal systems involved in generating various EEG patterns, whereas reviews with a more clinical view include those from Bennett et al., ${ }^{14}$ Jagadeesan et al., ${ }^{15}$ Marchant et al., ${ }^{16}$ and Purdon et al. ${ }^{17}$ These articles describe the changes in the raw EEG signal, ${ }^{14}$ and sometimes also how the mix of frequencies in the EEG signal change over time (e.g., the spectrogram). ${ }^{17}$ 


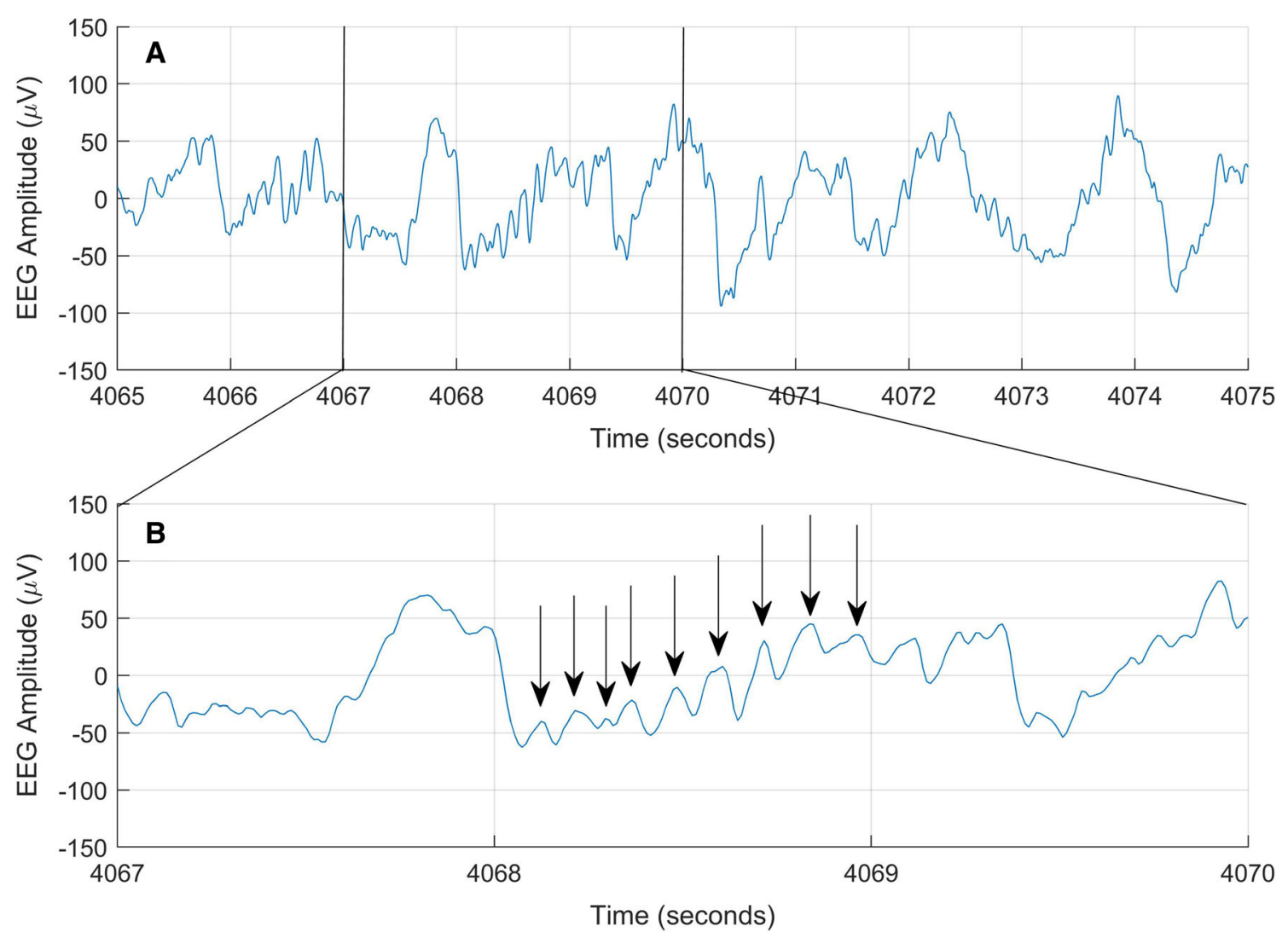

Fig. 3 Raw frontal electroencephalogram (EEG) trace of a slowwave/delta oscillation with ongoing alpha-spindle activity. The slowwave activity has a high amplitude of around $100 \mu \mathrm{V}$, with maximal voltage occurring every second or so. The alpha-spindle activity (oscillation peaks marked with arrows in the lower trace) is characterized by smaller voltage swings (around $40 \mu \mathrm{V}$ ) with peaks occurring approximately nine times per second $(9 \mathrm{~Hz})$ in this example. The upper tracing (A) shows ten seconds of EEG, and the lower tracing (B) three seconds of EEG taken from section A, as indicated by the vertical black lines

These articles also often mention the various types of noise that can manifest in the EEG (such as blinks, shown in Fig. 2 A), and some also show how the EEG changes in response to non-GABAergic anesthetic agents such as nitrous oxide and ketamine. The websites http://icetap.org and www.anesthesiaEEG.com also have useful information on the EEG during anesthesia.

The Table shows one of the many conventional nomenclatures applied to describe the frequency bands or components that are represented in complex EEG waves. These frequency bands are arbitrarily defined, and do not have specific neurobiological meaning.
Tracé brut d'un électroencéphalogramme (EEG) frontal d'une oscillation onde lente/delta avec une activité continue de fuseaux alpha. L'activité d'onde lente a une grande amplitude d'environ 100 $\mu \mathrm{V}$, le voltage maximal survenant environ à chaque seconde. L'activité de fuseaux alpha (pics d'oscillation marqués avec des flèches dans le tracé inférieur) se caractérise par des changements moins importants de voltage (environ $40 \mu \mathrm{V}$ ) et des pics survenant environ neuf fois par seconde $(9 \mathrm{~Hz})$ dans cet exemple. Le tracé supérieur (A) montre dix secondes d'EEG, et le tracé inférieur (B) trois secondes d'EEG pris de la section A, tel qu'indiqué par les lignes verticales noires

Insufficient anesthesia

Monitoring end-tidal volatile anesthetic concentration and maintaining adequate age-adjusted concentrations should be part of the anesthesiologist's approach to avoiding awareness with recall during volatile-based general anesthesia. Under-dosing is a particular risk when endtidal volatile anesthetic concentrations cannot be measured, e.g., during transfer between the induction room and operating room, the so-called "Mind the Gap" situation, ${ }^{18}$ when it seems unsafe to give age-adjusted concentrations consistent with adequate hypnosis, and when propofolmaintained anesthesia with neuromuscular blocking agents are used. When decreasing the administered anesthetic agent, the aforementioned continuous spindles usually increase in frequency before becoming intermittent, and 

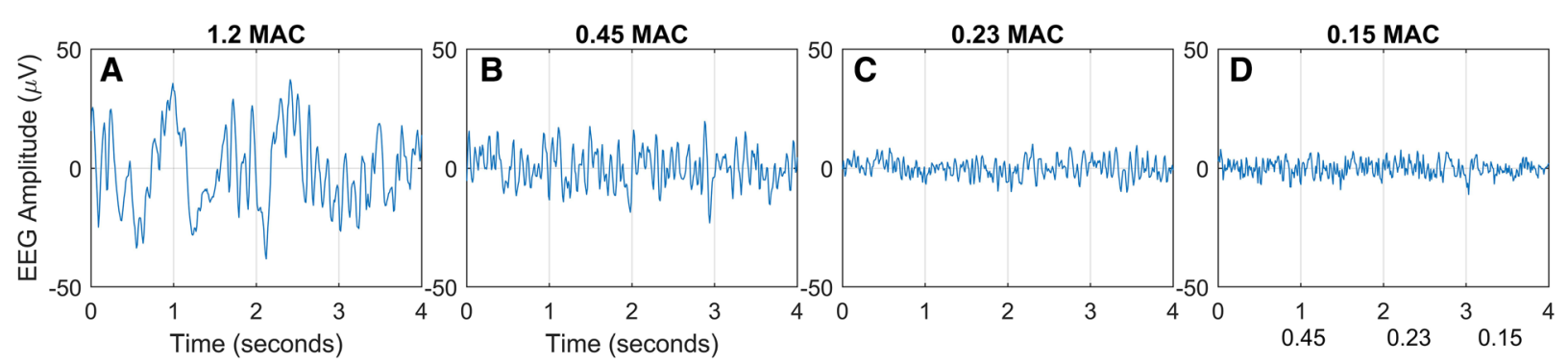

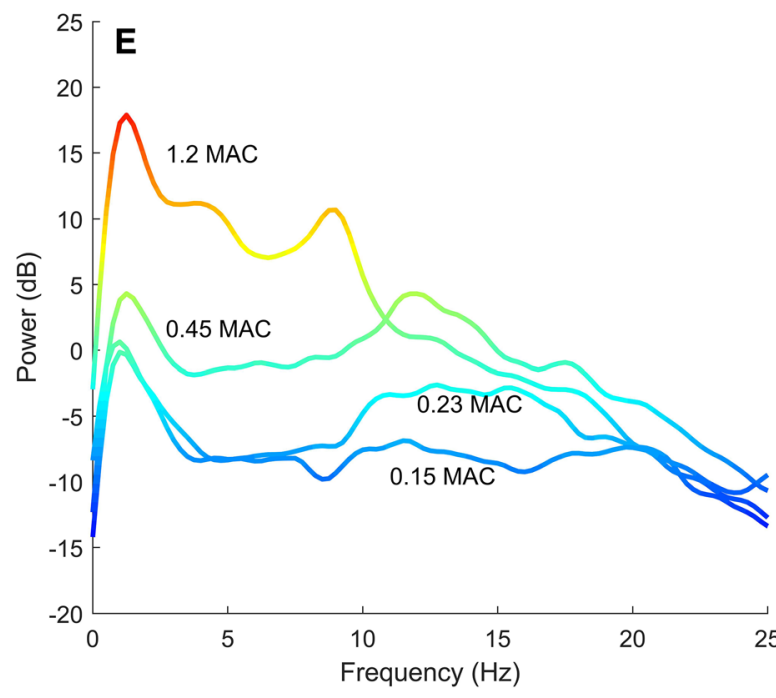

Fig. 4 Classic electroencephalogram (EEG) changes during emergence from general anesthesia following surgery. During emergence, amplitudes become smaller and frequencies increase in the raw EEG (sections A to D). Section E shows power spectra of the same time periods. Section F displays the density spectral array/ spectrogram showing the time course of emergence from which the sample raw EEG and power spectra are taken. Section $G$ illustrates an unintentional near-emergence case during cardiac surgery occurring when the administration of the volatile anesthetic transitions from the heart-lung machine to the ventilator (between 142 and $167 \mathrm{~min}$ )

then finally vanish (Fig. 4F). Depending on the age of the patient and effect site concentration of the hypnotic agents, there are important differences to detect: with comparable effect-site concentrations, alpha power and frequency both decrease with age. ${ }^{19}$ In general, alpha-spindle frequency usually slows with increasing effect-site concentration of volatile anesthetic agent. ${ }^{20}$

\section{Excessive anesthesia}

Observing the intraoperative EEG may also help avoid possible anesthetic overdosing in sensitive patients. The most obvious, although non-specific, EEG features of excessive anesthesia are burst suppression and persistent suppression. As the original minimum alveolar concentration (MAC) measure was derived based on
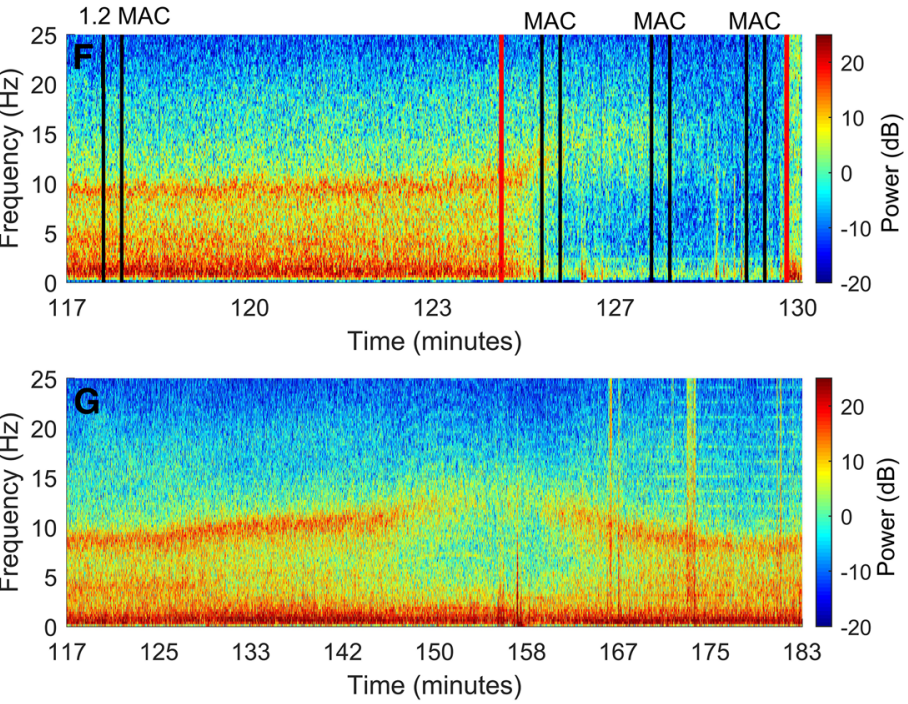

Changements typiques sur l'électroencéphalogramme (EEG) pendant le réveil de l'anesthésie générale après une chirurgie. Pendant le réveil, les amplitudes deviennent plus petites et les fréquences augmentent dans l'EEG brut (sections A à D). La section E montre les spectres de puissance des mêmes intervalles de temps. La section $\mathrm{F}$ affiche la matrice de densité spectrale / spectrogramme montrant l'évolution temporelle du réveil duquel l'exemple d'EEG brut et les spectres de puissance sont tirés. La section $\mathrm{G}$ illustre un cas accidentel de quasi-réveil pendant une chirurgie cardiaque survenu lorsque l'administration de l'anesthésique volatil passe du cœur-poumon artificiel (circulation extracorporelle) au respirateur (entre 142 et 167 $\min$ )

absence of movement in response to surgical stimulation (in 50\% of subjects), its dosing is to some degree based on anesthetic effect on the spinal cord, and not necessarily the cortex. ${ }^{21}$ This is why the introduction of a MAC measure that is dependent on some degree of EEG suppression may provide a more reliable measure of actual brain effect of volatile anesthetics. ${ }^{22}$ Although an association has been observed between the duration of EEG suppression and subsequent delirium, ${ }^{23}$ which may be especially relevant to older and/or more frail patients, it is not yet clear if prolonged EEG suppression is harmful. ${ }^{24}$ Observation of the EEG might give anesthesiologists a sense of the extent to which a particular patient's cortex is suppressed in response to a given anesthetic concentration. For example, the EEG can be used to detect patients who are 
unexpectedly sensitive to anesthetics because of systemic illness or other reasons.

\section{Various known noise effects on the EEG}

The EEG signal reflects electrical activity originating from the brain as well as from other sources, either within the body (e.g., heart and skeletal muscles) or outside the body (e.g., convection warmers), or from sources such as sweat or movement. Most of the review articles mentioned previously note the known effects of various non-neuronal sources on the EEG. In summary, these are:

Extraneous noise arises from all sorts of electrical equipment in the surgical environment. For example, from electrocautery for surgery (expressing as broadband noise over all frequency bands), and from the electrocardiogram (or ECG, where the rhythmic action of the heart is easy to spot). Artifacts are also introduced from patients being moved or from EEG electrodes being touched (resulting in large, very sudden, amplitude EEG shifts). In such situations, while the EEG signal can be temporarily distorted and uninterpretable, the hypnotic state of the patient may remain unchanged. Figure 5 shows an example of how electrocautery appears in both the raw EEG and in the spectrogram (sections $\mathrm{A}$ and $\mathrm{B}$ respectively).

Muscle activity is detected electrically as an electromyography (EMG) signal. EMG activity in the EEG can make the signal look 'fuzzy', as EMG activity is usually in the high frequency range $(>20 \mathrm{~Hz})$. Figure 5 shows an example of how EMG appears in both the raw EEG and in the spectrogram (sections $C$ and D respectively). In the spectrogram or density spectral array (DSA), muscle activity shows as increased power over multiple frequency bands (i.e., there is broadband noise). General anesthetic agents and neuromuscular blocking drugs decrease muscle activity, and therefore decrease EMG contamination of the EEG signal.

Additionally, some patients can have a small amplitude EEG; while it is known that EEG amplitude decreases with age, the remaining variance in amplitude may be possibly due to neurodegeneration or genetic factors. In such patients, one can be tempted to think that the EEG might be suppressed or isoelectric, but seeing how the signal responds to changing anesthetic concentration can sometimes clarify whether or not it is truly suppressed. It can also be helpful to decrease the amplitude scale (y-axis) for the EEG waveform, which is displayed in microvolts $(\mu \mathrm{V})$. A typical default amplitude scale is approximately 25-50 $\mu \mathrm{V}$ per $\mathrm{cm}$ on the display screen, depending on monitor. Reducing the scale to nearer to $20 \mu \mathrm{V}$ per $\mathrm{cm}$ can help to determine if smaller amplitude alpha-spindle and slow-wave oscillations are present.
Non-GABAergic anesthetics

The effect of anesthetic agents that do not act via the GABAergic pathway, such as nitrous oxide and ketamine are well known and are described in some of the review papers mentioned previously. When these agents are used, the frontal EEG will not show the classic features described previously. With both of these agents, the EEG will have a higher frequency component, and typically less power in the alpha range. The addition of ketamine infusions during propofol- or volatile-based general anesthesia can produce higher frequency waves, such as beta waves, in the EEG trace. These typically occur in addition to the patterns that are usually seen with these agents alone. In such cases, an EEG displaying more high frequency power will probably not represent a lighter state of anesthesia, but rather if administered as adjuncts to a GABAergic agent, the hypnotic state of the patient will likely be deeper. Dexmedetomidine and other alpha-2 agonists such as clonidine produce a slow-wave- dominant EEG with intermittent spindles. The EEG with alpha- 2 agonists has features in common with sleep (typically stages 2 and 3). ${ }^{17}$ In keeping with this observation, the sedated state produced by dexmedetomidine is much closer in some respects to that of sleep than to general anesthesia; while the EEG features might give the impression of deep anesthesia with higher concentrations of dexmedetomidine (i.e., large amplitude slow oscillations), a patient may abruptly awake from this state in response to a surgical stimulation.

\section{Unexpected non-linear EEG responses}

Given the "classic" population-level (average) EEG responses to increasing anesthetic concentration described in the previous section, an anesthesiologist might be forgiven for expecting such gradual and linear EEG changes in all of the patients they encounter in the operating room. Nonetheless, non-linear EEG responses to increasing or decreasing anesthetic concentrations such as either a non-changing or an abruptly changing EEG are comparatively common at the individual level. This section of the review aims to provide an update on two key nonlinear EEG phenomena that an anesthesiologist may encounter in the clinical situation, namely (i) some EEG responses to noxious stimulation and (ii) neural inertia.

Noxious stimuli and EEG response

At modest concentrations of anesthetic agents, the noxious stimulus of surgery will either cause no change in the EEG - if analgesia is adequate-or cause thalamocortical depolarization. In this situation, the EEG might present with a loss of slow waves and an increase in high- 


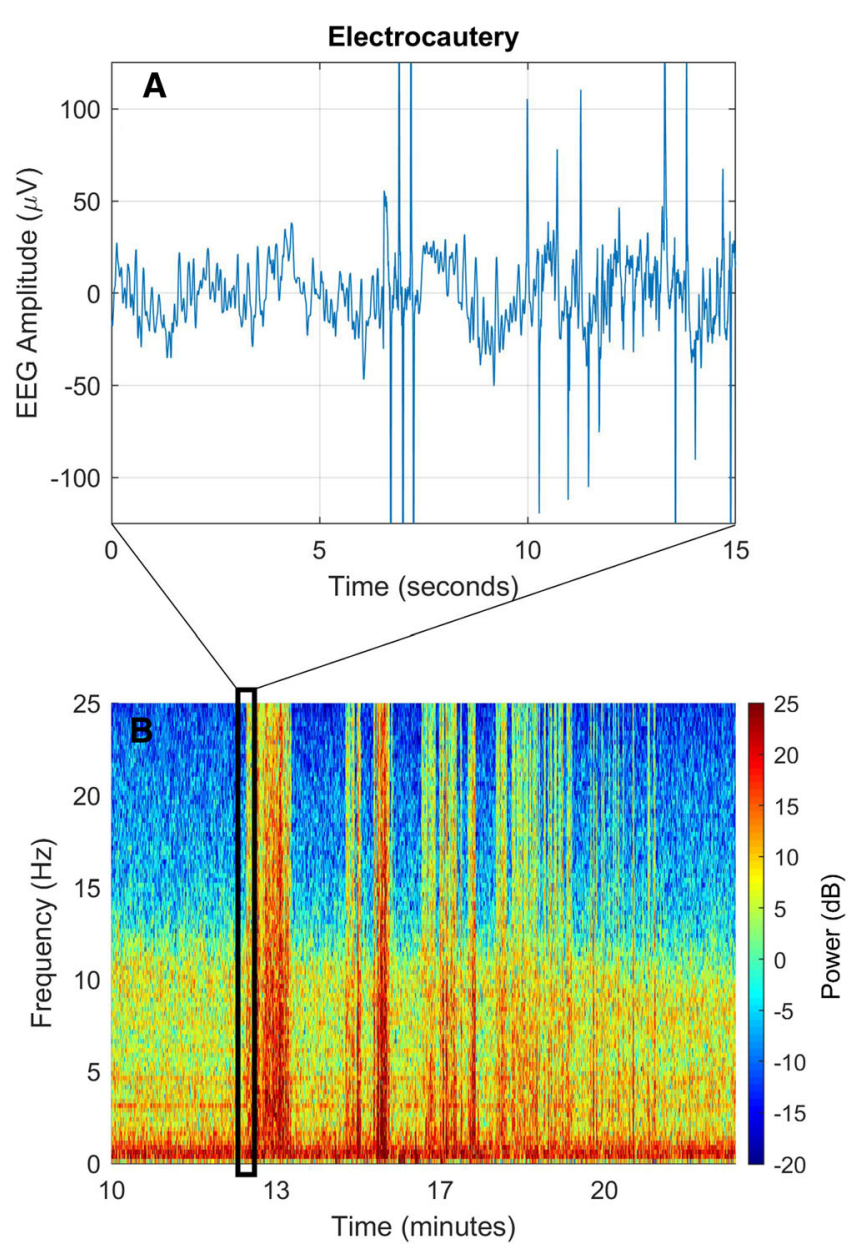

Fig. 5 Examples of how both noise from electrocautery and electromyogram (EMG) (muscle activity) appear in the raw electroencephalogram (EEG) and in the spectrogram. Section A shows sharp high-amplitude spikes resulting from electrocautery on top of an ongoing oscillation. In the spectrogram (section B) this appears as high power over a broad frequency range. Section $\mathrm{C}$ shows the onset of EMG activity in the raw EEG (where the trace becomes slightly "fuzzy" after seven seconds because of high frequency activity). In the spectrogram (section D), EMG onset also appears as increased power over higher frequencies

frequency (beta and gamma) waves. The increase in high frequencies is known as "beta arousal", and is similar to the commonest pattern of emergence at the end of anesthesia (Fig. 4). In contrast "delta arousal" (also termed "paradoxical arousal") is an unexpected increase in slow-wave or delta EEG amplitude in response to noxious surgical stimulation-particularly visceral stimulation (Fig. 6). ${ }^{25}$ This unexpected EEG response was first reported in the early $90 \mathrm{~s},{ }^{26}$ but has seldom received attention since then. ${ }^{27}$

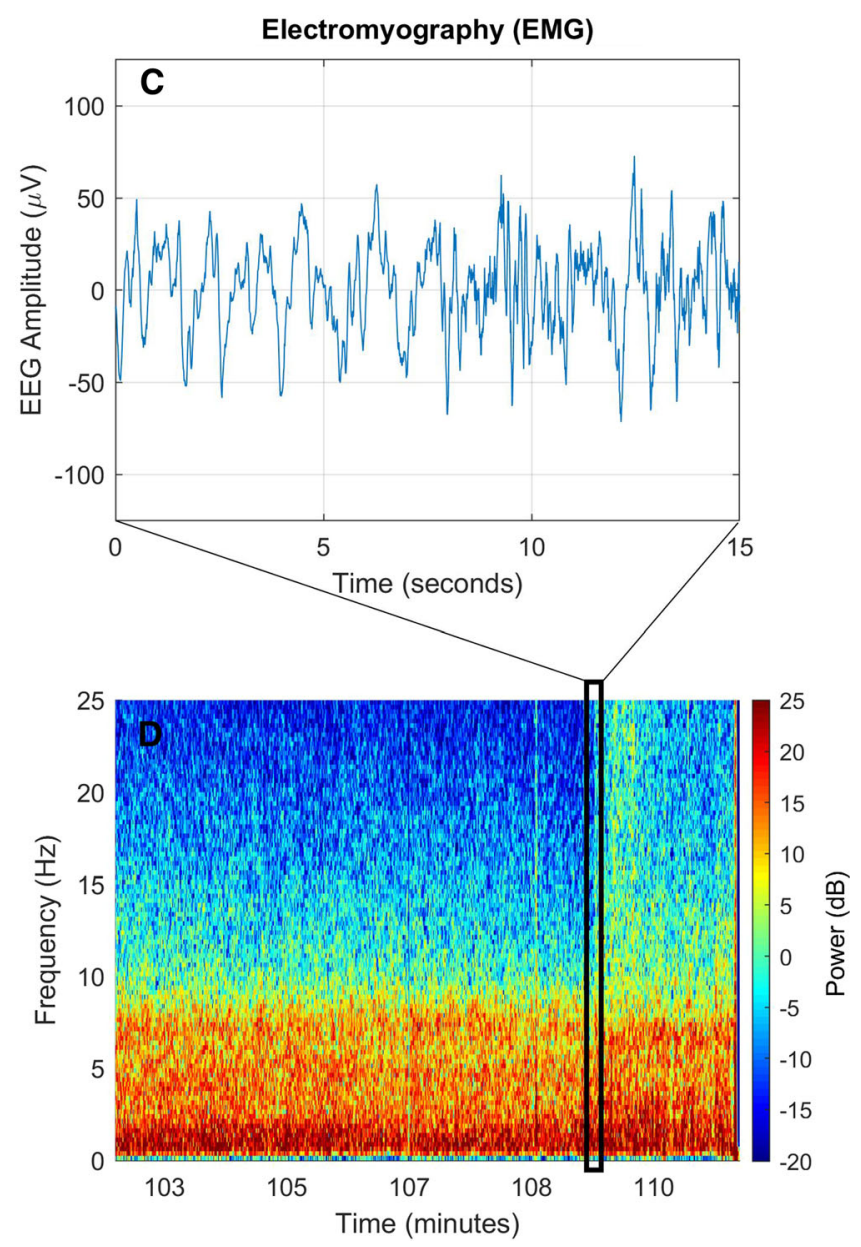

Exemples de la façon dont les bruits provenant de l'électrocautérisation et de l'électromyogramme (EMG) (activité musculaire) apparaissent sur l'électroencéphalogramme (EEG) brut et sur le spectrogramme. La section A montre des pointes aiguës de grande amplitude résultant de l'électrocautérisation au-dessus d'une oscillation continue. Dans le spectrogramme (section B), cela est représenté comme une puissance élevée sur une vaste bande de fréquences. La section $\mathrm{C}$ montre le début de l'activité liée à l'EMG dans l'EEG brut (lorsque le tracé devient un peu flou après sept secondes en raison de l'activité de haute fréquence). Dans le spectrogramme (section D), le début de l'EMG apparaît également sous forme de puissance accrue sur les fréquences plus élevées

In this situation the clinician should not decrease the administration of the general anesthetic agent (e.g., volatile agent or propofol) unless other clinical signs of inadequate anesthesia are present as this may lead to inadequate anesthesia; rather, it has been suggested that increasing analgesic administration would be more appropriate. It is worth noting that delta arousal might be a sign of endogenous anti-nociceptive activation. As noted ${ }^{28,29}$ some individuals can also show other specific expressions of a sudden EEG change in response to a noxious 
stimulation, such as sudden loss of power in the alpha range-a so-called alpha dropout ${ }^{30}$ (Fig. 6). The causes of these varied phenomena remain unknown.

\section{Neural inertia}

While induction of general anesthesia with loss of consciousness is an "active" drug-induced alteration of brain function, emergence from anesthesia with return of consciousness has been conceived as a mirror image "passive" process, occurring with elimination of anesthetic drugs from the central nervous system. If this conceptualization were true, anesthetic concentrations at loss of consciousness on induction and at return of consciousness on emergence would be identical. Nevertheless, recent studies in mice and fruit flies, ${ }^{31}$ as well as in humans, ${ }^{32,33}$ report substantially lower hypnotic drug concentrations (e.g., volatile agent) at recovery of consciousness compared with at loss of consciousness. This is likely not just a pharmacokinetic confound, but rather suggests that different mechanisms are involved in the induction and emergence processes. ${ }^{34}$ All these studies suggest that hysteresis is more marked in situations where arousal neuromodulators are impaired (e.g., old age, narcolepsy, droperidol, clonidine, and antimuscarinic drugs).

Clinicians need to be cautious when decreasing (volatile) anesthetic concentration to below the concentration required to render a patient unconscious, trusting in an EEG pattern that shows features suggestive of general anesthesia (see Fig. 7). Brain dynamics are often not monotonic or stable during various states, including sleep and general anesthesia. Therefore, during emergence from general anesthesia (or if the anesthesiologist is intentionally attempting to maintain "light" general anesthesia, just above the threshold of wakefulness) it cannot be predicted exactly when a particular patient may switch from being unconscious to being conscious and responsive. Furthermore, since there is probably hysteresis between the concentration of hypnotic anesthetic agent required to engender unconsciousness and the concentration at which consciousness returns, when consciousness does (eventually) return, a large increase in hypnotic agent might be required to restore unconsciousness. Another way of stating this, is that $\mathrm{MAC}_{\text {awake }}$ is probably a lower concentration than $\mathrm{MAC}_{\mathrm{LOC}}$ (loss of consciousness). This probably applies to both individual patients and a population.
Some unsolved problems, and the future of EEG-based brain monitoring

Responsiveness despite a frontal EEG pattern of "deep" anesthesia

Recent research using the isolated forearm technique has shown that in some rare situations, a patient with a frontal EEG pattern consistent with general anesthesia (i.e., strong slow-wave and alpha-spindle activity), may still be-to some degree-conscious of, and connected to, the environment, evidenced by some response to a command. ${ }^{35}$ While such occurrences are quite rare, and the clinical relevance of such states is still debated, ${ }^{36}$ this phenomenon suggests that volatile anesthetics may cause more of a dissociated state than has been previously assumed. Put in more philosophical terms, it may be that anesthesiologists are not necessarily always decreasing the level of consciousness, but rather sometimes only degrading the contents of consciousness. ${ }^{37}$

One response to this observation is that while slow-wave and alpha-spindle activity are indeed the most relevant measures of an adequate level of anesthesia, we might simply have been looking at the wrong location. The front of the forehead is free of hair and provides easy and stable access for EEG electrodes, but these pragmatic issues do not determine the best location for assessing unconsciousness. Some authors have recently posited a posterior "hot-zone" where the neurons responsible for phenomenal consciousness are proposed to be located. ${ }^{38}$ But the jury is still out on this issue.

A second response is that unconsciousness might not invariably be associated with any particular EEG measure taken from a single location (although there are no reports to date of responsive patients with frontal EEG patterns showing burst suppression or persistent suppression), but is rather dependent on some kind of connectivity between two or more brain areas. For example, connectivity measures between frontal and parietal areas have been shown to decrease when loss of responsiveness occurs, and that not only for sevoflurane and propofol, but also for the non-GABAergic agent ketamine. ${ }^{39}$ Nonetheless, there are many different measures of connectivity, and it has not yet been conclusively decided which one is best. These observations call into question the perspective that a frontal EEG consisting of slow-wave and alpha-spindle activity is a genuine expression of a hyperpolarized thalamocortical system, and thus provides a reliable 

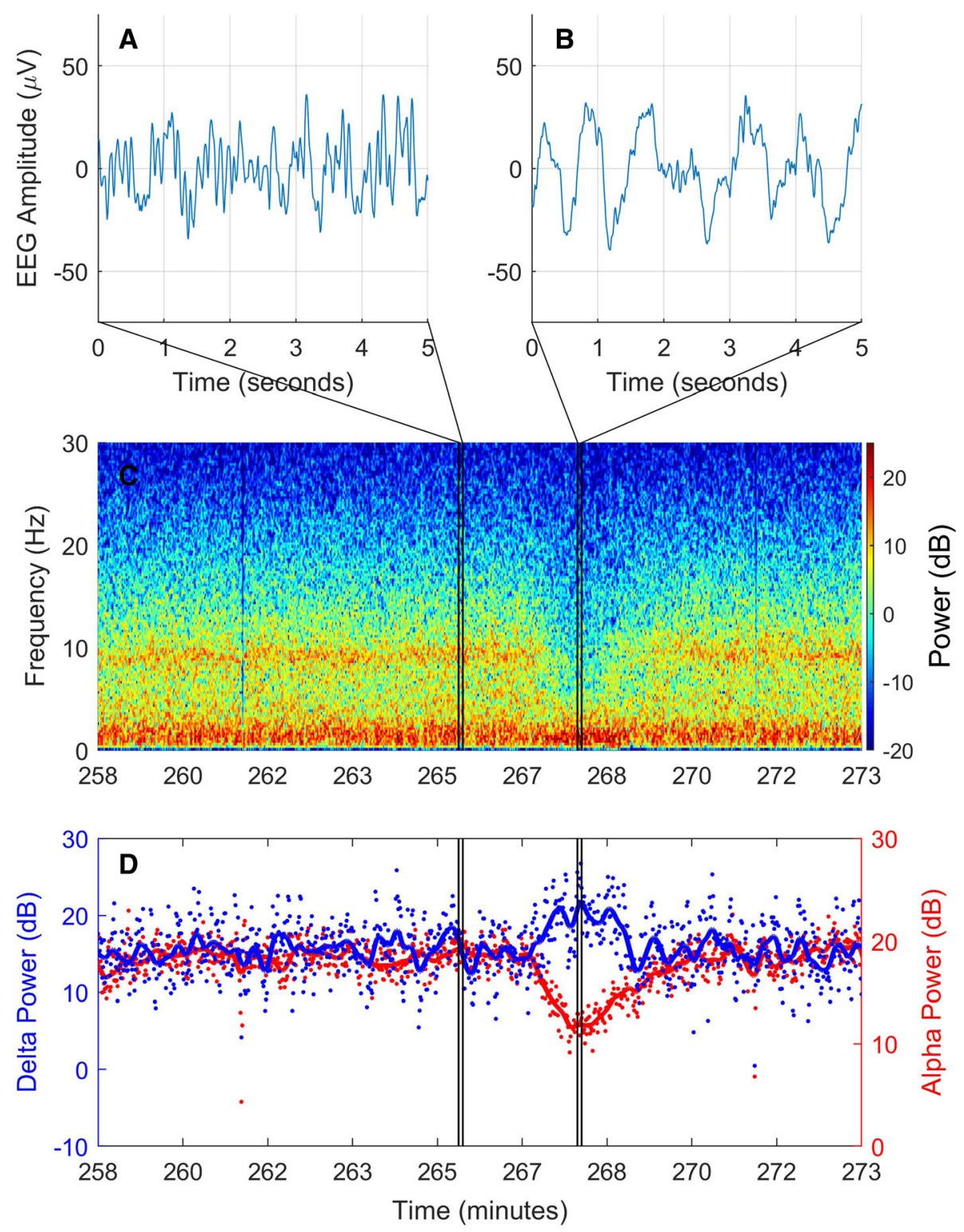

Fig. 6 Non-linear unexpected changes in the electroencephalogram (EEG) in response to surgical noxious stimulation. Despite unchanged volatile agent concentration, the EEG shows both a loss of the alphaspindle oscillation (around $9 \mathrm{~Hz}$ in this patient) called an alpha dropout, and a concurrent increase in delta power $(0.5-4 \mathrm{~Hz}$ in this example), also known as delta arousal. In section $\mathrm{D}$, the mean power in the alpha and delta frequency ranges is portrayed over time. This is an alternative representation of the colour of the spectrogram within the frequency ranges, where red represents high power and blue represents low power (see colour bar on the right side of the spectrogram in section $\mathrm{C}$ )

correlate of unconsciousness. Clearly, we have not yet found the precise neural correlates of unconsciousness. These cautions and unsolved problems are not a reason to ignore the EEG in patients who do have a classic
Changements non linéaires inattendus sur l'électroencéphalogramme (EEG) en réaction à une stimulation chirurgicale douloureuse. Malgré une concentration d'agent volatil inchangée, l'EEG montre à la fois une perte de l'oscillation des fuseaux alpha (environ $9 \mathrm{~Hz}$ chez ce patient), appelé perte de signal alpha, et une augmentation concomitante de la puissance delta $(0,5-4 \mathrm{~Hz}$ dans cet exemple), soit un éveil delta. Dans la section D, la puissance moyenne dans les bandes de fréquence alpha et delta est décrite au fil du temps. Il s'agit d'une représentation alternative de la couleur du spectrogramme dans les bandes de fréquence, où le rouge représente une puissance élevée et le bleu une puissance faible (voir la barre de couleur à droite du spectrogramme dans la section C)

concentration-response relationship, ${ }^{40}$ but rather clarify the main goal: any future EEG measure of unconsciousness has to be founded on the neurobiological correlates of unconsciousness. $^{41}$ 

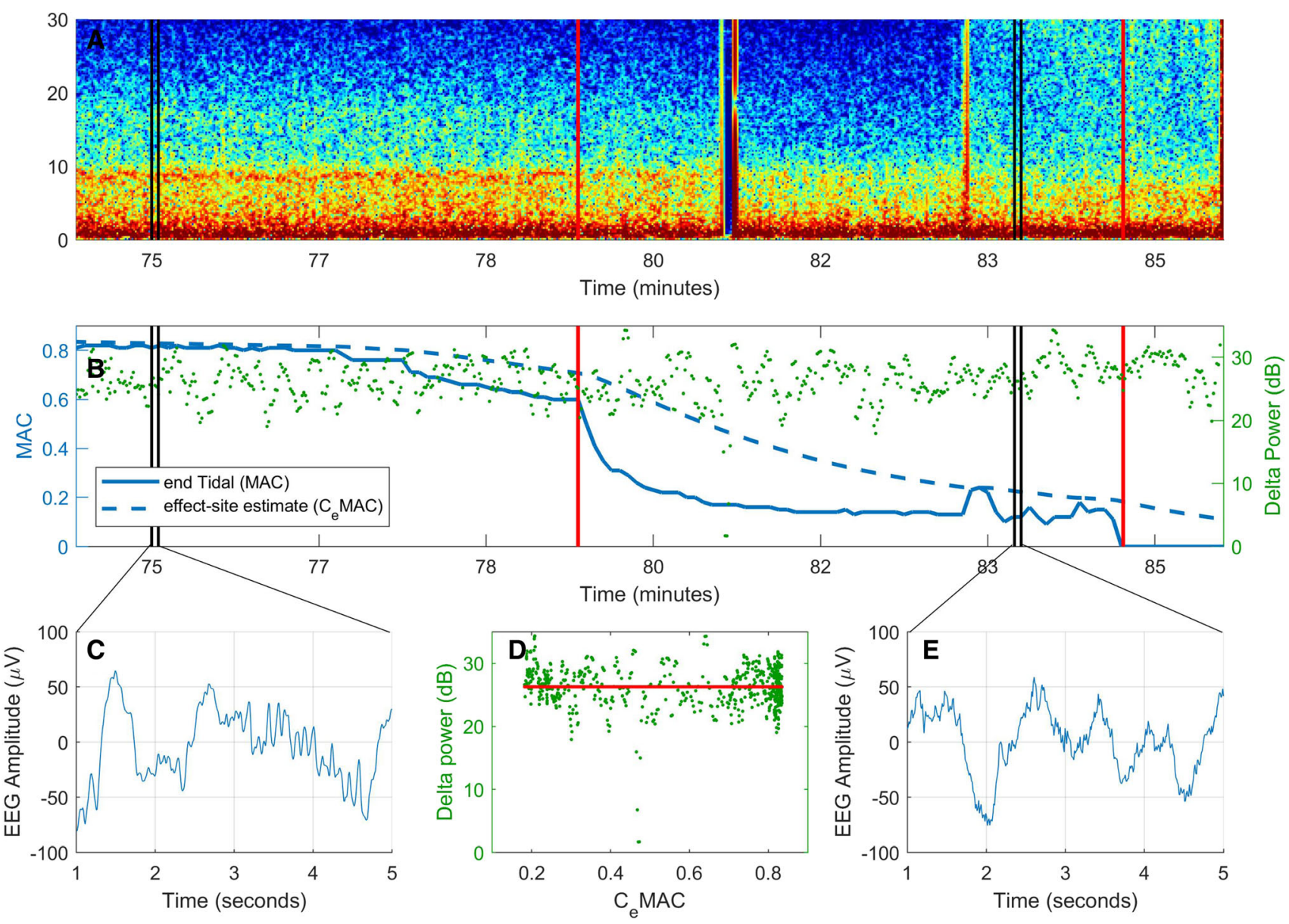

Fig. 7 An electroencephalogram (EEG) signature of neural inertia during emergence from general anesthesia. The start of emergence occurs at 79 min (red line, sections A and B), where end-tidal volatile concentration decreases sharply (section B), and patient becomes responsive at around 84 min (second red line, sections A and B). In section A, a spectrogram shows a decrease in alpha-spindle power (around $9 \mathrm{~Hz}$, colour changes from red to orange), and an increase in EMG activity (in the $10-30 \mathrm{~Hz}$ range) during emergence. Nonetheless, delta power (as shown in sections B [against time] and section D [against effect-site minimum alveolar concentration]) does not decrease at all over emergence. The sections of raw EEG in section C (general anesthesia) and section E (just prior to waking) are taken from between the sets of thin vertical black lines in B and A, and show a very similar morphology

\section{Conclusions}

Our understanding is evolving in relation to the neurobiology of consciousness, and to the mechanisms underlying anesthetic-induced unconsciousness. At the same time, we are developing a more nuanced understanding regarding the utility of the EEG as a monitor during intended general anesthesia, as well as an appreciation of some potential limitations of current EEG
Une représentation sur l'électroencéphalogramme (EEG) d'inertie neurale pendant le réveil de l'anesthésie générale. Le début du réveil survient à 79 min (ligne rouge, sections $\mathrm{A}$ et B), alors que la concentration volatile télé-expiratoire chute brusquement (section B) et le patient devient réactif vers 84 min (deuxième ligne rouge, sections A et B). Dans la section A, un spectrogramme montre une réduction de la puissance des fuseaux alpha (environ $9 \mathrm{~Hz}$, la couleur passe de rouge à orange) et une augmentation de l'activité sur l'EMG (dans la bande 10-30 Hz) pendant le réveil. Toutefois, la puissance delta (comme décrit dans les sections B [contre le temps] et $\mathrm{D}$ [contre la concentration alvéolaire minimale au site effecteur]) ne diminue pas du tout au réveil. Les sections d'EEG brut dans la section $C$ (anesthésie générale) et la section $\mathrm{E}$ (juste avant le réveil) sont prises d'entre les ensembles de lignes verticales noires minces dans B et A, et ont une morphologie très similaire

applications. Common approaches that we have used historically, such as Fourier analysis to deconstruct the complex EEG waveform into arbitrarily defined frequency bands, can be associated with loss of valuable information. For example, relationships between different EEG frequencies (cross frequency relationships) are likely to have neurobiological relevance. Furthermore, focusing on a single EEG channel precludes the assessment of EEG relationships across the cortex. There is probably not a 
single unitary mechanism of anesthetic action with different anesthetic drugs and drug combinations. It is also exceedingly unlikely that there is a single EEG signature that applies to all patients of all ages, regardless of drug combinations and independent of intensity of surgical stimulation. It is therefore important for anesthesia clinicians who incorporate EEG brain monitoring into their practice to appreciate both its strengths and limitations. It is unsurprising that the body's most complicated organ is proving to be challenging to monitor accurately during general anesthesia. Nevertheless, if we anesthesiologists hope to deliver precision medicine to our patients in the operating room and intensive care unit, the brain is clearly the logical target for achieving this.

\section{Clinical case scenario}

A 58-yr-old man with hypertension and obesity is undergoing a laparoscopic right hemicolectomy under combined transversus abdominis plane (TAP) block and general anesthesia, with sevoflurane and fentanyl. The induction of anesthesia is uneventful, but before incision and during insufflation of carbon dioxide into the peritoneum, the patient becomes hypotensive, which resolves with your treatment. For the next $90 \mathrm{~min}$, maintenance of anesthesia is stable, without major hemodynamic or electroencephalogram (EEG) changes, while the surgeon is dissecting through abdominal adhesions. After accidentally lacerating the bowel, the surgeon decides to switch to an open procedure and performs a laparotomy. You notice a sudden change in the raw EEG and density spectral array (DSA), which you address appropriately. The surgery progresses well until there is severe blood loss due to a tear in the inferior vena cava. Because of the hemodynamic instability, you decrease the volatile anesthetic administration to around 0.4 minimum alveolar concentration while you resuscitate the patient. During the resuscitation of the patient, the EEG changes go unnoticed. You are glad when the patient is finally stable, and you recognize tall delta waves during irrigation of the abdomen close to the end of the operation.

\section{Instructions for completing the continuing professional development (CPD) module:}

1. Read the current article and the references indicated in bold.

Go to: https://www.cas.ca/en/education/continuingprofessional-development/cpd-modules to access our learning management system, $\log$ in and select the current module (An updated introduction to electroencephalogrambased brain monitoring during intended general anesthesia). Your username is your email address in the member directory and your password is your Canadian Anesthesiologists' Society identification number. This module is accredited for three years. You can find the exact accreditation period on the CAS website and in the learning management system.

2. Answer the multiple choice questions regarding the case scenario.

3. Once you have entered all your answers, you will have access to experts' explanations for all the possible choices.

4. Participants may claim up to four hours of CPD under Section 3 of the MOC Program of the Royal College of Physicians and Surgeons of Canada.

Table 1 Typical nomenclature for frequency bands within the EEG

\begin{tabular}{ll}
\hline Name of frequency band & Frequency band (in Hertz) \\
\hline Slow wave (sometimes also named Delta) & $0-1 \mathrm{~Hz}$ \\
Delta & $1-4 \mathrm{~Hz}$ (but sometimes $0-4 \mathrm{~Hz})$ \\
Theta & $4-8 \mathrm{~Hz}$ \\
Alpha & $8-12 \mathrm{~Hz}$, also called mu, if recorded from motor cortex \\
Sigma & $12-14 \mathrm{~Hz}$; often the frequency band for sleep spindles during physiologic sleep \\
Beta & Generally $12-30 \mathrm{~Hz}($ or $14-30 \mathrm{~Hz})$, but also \\
& Low Beta $(<20 \mathrm{~Hz})$ \\
Gamma & High Beta $(20-30 \mathrm{~Hz})$ \\
& $>30 \mathrm{~Hz}$ (up to $100 \mathrm{~Hz})$
\end{tabular}

In patients who do show a typical concentration-response effect in their frontal EEG, the EEG can be used to guide titration of anesthetic dosing to prevent both insufficient and possibly excessive anesthetic dosing. EEG = electroencephalogram 


\section{Une introduction mise à jour du monitorage cérébral par encéphalogramme pour une anesthésie générale planifiée}

\section{Objectifs de ce module de Développement professionnel continu:}

Après avoir lu ce module, le lecteur devrait être en mesure de:

1) Formuler les concepts fondamentaux des changements typiques observés à l'électroencéphalogramme (EEG) pendant une anesthésie générale avec des agents volatils ou du propofol.

2) Différencier une « hypnose » excessive, adéquate ou possiblement insuffisante pendant une anesthésie générale planifiée en observant le tracé de l'EEG.

3) Appliquer les informations acquises à partir du tracé brut de l'EEG ou de sa matrice de densité spectrale / spectrogramme afin de guider l'administration d'agents anesthésiques volatils ou intraveineux.

4) Reconnaître certaines situations moins fréquentes dans lesquelles les caractéristiques de l'EEG frontal semblent en désaccord avec l'état du cerveau en fonction du comportement du patient.

Le cerveau étant l'organe distinctif du genre humain, il est surprenant qu'il s'agisse du seul organe vital dont la fonction n'est pas monitorée de façon routinière en salle d'opération ou à l'unité de soins intensifs. L'explication la plus plausible est que, au contraire des reins, du cœur, des poumons ou du foie, nous n'avons pas été capables de monitorer facilement les aspects du fonctionnement cérébral pendant l'inconscience induite par des agents pharmacologiques. En médecine clinique, la seule façon de monitorer de façon fiable certaines fonctions cérébrales consiste à le faire lorsque les individus sont conscients; en observant leurs interactions avec l'environnement, nous pouvons généralement déterminer si leurs cerveaux fonctionnent bien. Étant donné que l'état conscient dépend de l'activité neuronale, et que les anesthésiques généraux ont un effet perturbateur au niveau neuronal, une mesure de l'activité neuronale lorsque la réactivité et la mémoire sont perturbées devrait intéresser tous les anesthésiologistes. L'électroencéphalogramme (EEG) est une mesure facile à obtenir de l'activité neurale qui quantifie de manière non invasive, à partir du cuir chevelu, l'activité électrique additionnée et synchrone de millions de neurones dans le cortex cérébral.
En 1937, Gibbs, Gibbs et Lennox recommandaient aux anesthésiologistes de systématiquement utiliser l'EEG pour monitorer le « dysfonctionnement cérébral » engendré par l'anesthésie générale. ${ }^{1}$ Toutefois, ce n'est que depuis quelques décennies que les anesthésiologistes utilisent régulièrement ces informations pour les aider à réaliser une anesthésie générale. L'objectif de ce compte rendu est de résumer l'état actuel des connaissances concernant l'utilisation de l'EEG pendant une anesthésie générale planifiée. La première partie résumera les changements typiques de l'EEG frontal lors d'une augmentation de la concentration anesthésique, et la deuxième partie présentera des cas dans lesquels l'EEG pourrait ne pas changer de façon typique lors d'une augmentation ou d'une réduction de la concentration anesthésique. Une dernière partie portera sur les problèmes irrésolus et les orientations futures du monitorage par EEG pendant l'anesthésie générale. Il convient de noter que ce compte rendu n'abordera pas les indices EEG traités ou brevetés, mais se concentrera plutôt sur le signal EEG non traité tel qu'il est affiché par tous les moniteurs.

Trois affichages de l'EEG : l'amplitude dans le temps (EEG brut), la puissance sur la fréquence (spectre de puissance) et la puissance par fréquence dans le temps (spectrogramme)

Trois façons classiques de visualiser l'EEG seront utilisées dans cet article. La première consiste à visualiser les fluctuations dans l'amplitude de l'EEG (mesurées en microvolts, $\mu \mathrm{V}$ ) telles qu'elles surviennent dans le temps. On appelle ce tracé l'EEG brut, tel qu'exemplifié dans la figure 1. De cette perspective (également nommée le domaine temporel), on peut voir la morphologie de la forme d'onde de l'EEG et estimer visuellement la fréquence d'une oscillation en comptant le nombre de pics d'oscillation par seconde (voir également la figure 3). Néanmoins, parce qu'un EEG typique pendant une anesthésie générale consiste en un mélange d'oscillations de différentes amplitudes et fréquences, une deuxième vue - le spectre de puissance - est utile. Pour créer un spectre de puissance (qu'on appelle également le domaine fréquentiel), une section de l'EEG est transformée à l'aide d'une transformation de Fourier, qui calcule une valeur de puissance (amplitude au carré $[\mu \mathrm{V}]^{2}$ pour chaque domaine ou bande de fréquence. Comme le spectre de puissance quantifie la mesure dans laquelle les oscillations dans chaque fréquence contribuent à la section d'EEG, il arrive parfois qu'il révèle du contenu de fréquence qui pourrait ne pas être visible à l'œil nu dans le domaine temporel. La troisième vue de l'EEG, le spectrogramme, affiche la façon dont la puissance à chaque fréquence de l'EEG se modifie dans le temps, c'est-à-dire dans des 
sections successives de l'EEG. Afin de créer cette vue, les valeurs de puissance du spectre de puissance sont distinguées par un code couleur, le rouge marquant une puissance élevée et le bleu une puissance faible (voir figure 2 rangée 2). Une fenêtre d'analyse est ensuite balayée sur le tracé de l'EEG, produisant des spectres de puissance successifs, qui sont ensuite visualisés d'en haut, où la fréquence est sur l'axe des ordonnées (y), le temps sur l'axe des abscisses (x), et la puissance est présentée sous forme d'échelle de couleur. L'avantage de cette perspective est qu'elle permet de déceler les changements subtils du contenu de la fréquence de l'EEG sur de longues périodes (c.-à-d. des heures).

Changements typiques observés sur l'EEG frontal lors de l'augmentation des concentrations d'anesthésiques

Lorsqu'un patient reçoit des doses croissantes d'anesthésiques GABAergiques (acide gammaaminobutyrique) tels que des agents volatils à base d'éther ou du propofol (voir par exemple les références ${ }^{2}$ et, ${ }^{3}$ dans la vaste majorité des cas, on peut observer des changements prévisibles au niveau de l'EEG frontal et ce, malgré la variabilité qui existe tant inter- que intrapatient. Trois tracés oscillatoires classiques sont décrits avec une anesthésie générale «classique». Ces oscillations caractéristiques sont des ondes lentes $(<1 \mathrm{~Hz})$, des ondes delta (1-4 Hz), et des fuseaux / activité alpha continus $(8-12 \mathrm{~Hz})$. Dans cet article, nous avons retenu le terme de 'fuseaux alpha' pour décrire l'activité oscillatoire pendant l'anesthésie générale qui se retrouve principalement dans la bande de fréquence alpha traditionnelle de $8-12 \mathrm{~Hz}$. Nous émettons deux mises en garde toutefois : premièrement, ces mêmes oscillations peuvent parfois être plus rapides ou plus lentes qu'une onde alpha typique (par ex., elles sont plus lentes lorsque le patient est plus âgé, ou lors d'une augmentation de la concentration d'anesthésique volatil), et deuxièmement, elles sont différentes du fuseau dans un sommeil de stade $\mathrm{N} 2$ en ce qu'elles sont plus continues et localisées de manière plus frontale (voir figure 1). On pense que ces oscillations sont générées par le système thalamo-cortical agissant comme un réseau complexe. ${ }^{4}$ Les fuseaux résultent probablement d'activités répétitives et alternantes de pointes (spike) et de bouffées (burst) dans les neurones réticulaires thalamiques produisant des potentiels post-synaptiques inhibiteurs rythmiques dans les neurones thalamo-corticaux. Les oscillations delta pendant l'anesthésie pourraient représenter un niveau encore plus hyperpolarisé de potentiels membranaires des neurones thalamo-corticaux que lorsqu'il n'y a qu'une génération de fuseaux. $^{5}$ Lorsque les neurones thalamo-corticaux sont hyperpolarisés, les influences environnementales, comme par exemple les stimuli chirurgicaux douloureux, sont généralement partiellement atténuées dans leur transmission via le thalamus au cortex. Les neurones réticulaires thalamiques (qui entourent le thalamus), les neurones intra-thalamiques et les neurones corticaux sont probablement tous capables de générer des rythmes à faible fréquence associés à l'anesthésie générale. ${ }^{6}$

À des concentrations anesthésiques provoquant une légère sédation, la forme d'onde de l'EEG frontal est habituellement dominée au début par une activité bêta lente, dénotant une activité d'environ $12-20 \mathrm{~Hz}$. Le patient pourrait manifester des signes d'excitation paradoxale pendant cette période. Au fur et à mesure que le patient devient moins réactif à des concentrations médicamenteuses plus élevées, on observe en général un ralentissement de la bande de fréquence alpha $(8-12 \mathrm{~Hz})$ (figure 2, parties B et C) ${ }^{8,9}$ Lorsqu'un individu est éveillé et détendu avec les yeux fermés, un rythme postérieur dominant (alpha) est habituellement apparent à l'EEG sur les régions occipitales et pariétales. Pendant la perte de réactivité (induction de l'anesthésie), cette puissance dominante dans la bande de fréquence alpha se déplace des zones occipitale et pariétale aux zones frontales du cerveau, un phénomène qu'on appelle l'antériorisation, ${ }^{10}$ ce qui rend le monitorage de l'EEG frontal pendant l'anesthésie à la fois faisable et pratique.

Après la perte de réactivité, une oscillation plus lente (1-4 Hz) apparaîtra également à l'EEG, qu'on appelle souvent activité lente profonde ou activité delta (voir figures $2 \mathrm{C}$ et 3 ). Une augmentation supplémentaire de la dose hypnotique génère des périodes de suppression de l'EEG (c.-à-d. une faible amplitude, souvent inférieure à 5 $\mu \mathrm{V})$ entrecoupée d'activités de bouffées d'amplitude élevée $(>20 \mu \mathrm{V})$, qu'on appelle bouffées suppressives (ou silences périodiques, burst suppression) (figure 2, colonne $\mathrm{D}$, rangée 1 ), avant de finalement devenir un EEG plat de façon continue (l'absence complète de toute oscillation visible) à des concentrations anesthésiques élevées. Dans le spectre de puissance (figure 2, colonne $\mathrm{D}$, rangée 2), les bouffées se manifestent comme des périodes de puissance élevée dans toutes les fréquences, et des périodes de suppression en tant que puissance basse dans toutes les fréquences. Sur le spectrogramme (figure 2, colonne $\mathrm{D}$, rangée 3 ), les périodes de suppression se présentent sous forme de rayures perpendiculaires très définies de couleurs plus froides (bleu).

Ces réactions classiques de l'EEG à des concentrations anesthésiques croissantes ont été illustrées dans de nombreux articles au fil des décennies. Parmi les premiers articles dignes de mention et exhaustifs, citons les articles de Rampil ${ }^{11}$ et Jameson et Sloan. ${ }^{12}$ Plus tard, Brown et coll. ${ }^{13}$ se sont concentrés sur les systèmes d'émergence impliqués dans la génération de divers tracés d'EEG, alors que les comptes rendus de Bennett et coll., ${ }^{14}$ 
Jagadeesan et coll. ${ }^{15}$ Marchant et coll. ${ }^{16}$ et Purdon et coll. ${ }^{17}$ proposent une approche plus clinique. Ces articles décrivent les changements au niveau du signal brut $\mathrm{d}^{\prime} E E G,{ }^{14}$ et parfois la manière dont le mélange de fréquence dans le signal d'EEG se modifie au fil du temps (par ex., le spectrogramme). ${ }^{17}$ De plus, ces articles mentionnent souvent les différents types de bruits qui peuvent se manifester sur l'EEG (tels que des clignotements (blinks), comme illustré à la figure $2 \mathrm{~A}$ ) et certains montrent également comment l'EEG change en réponse aux agents anesthésiques non GABAergiques tels que le protoxyde d'azote et la kétamine. Les sites internet http://icetap.org et www.anesthesiaEEG.com contiennent également des informations utiles sur l'EEG pendant l'anesthésie.

Le tableau présente l'une des nombreuses nomenclatures conventionnelles appliquées pour décrire les bandes de fréquence ou les composantes représentées dans des ondes d'EEG complexes. Ces bandes de fréquence sont définies de manière arbitraire, et n'ont pas de signification neurobiologique spécifique.

\section{Anesthésie insuffisante}

Le monitorage de la concentration d'anesthésique volatil télé-expiratoire et le maintien de concentrations ajustées en fonction de l'âge adéquates devraient faire partie de l'approche de l'anesthésiologiste pour éviter l'état d'éveil avec rappel pendant une anesthésie générale par agents volatils. Le sous-dosage constitue un risque particulier lorsque les concentrations télé-expiratoires de l'anesthésique volatil ne peuvent être mesurées, comme par exemple pendant le transfert entre la salle d'induction et la salle d'opération, une situation qu'on appelle 'Mind the Gap' en anglais (jeu de mots sur l'avertissement du métro de Londres et le sens d'esprit de 'mind'), ${ }^{18}$ ou lorsqu'il semble non sécuritaire de donner des concentrations ajustées selon l'âge correspondant à une hypnose adaptée, et lorsqu'on utilise une anesthésie maintenue au propofol avec des curares. Lorsque la concentration d'agent anesthésique administré est réduite, les fuseaux continus mentionnés plus haut augmentent généralement en fréquence avant de devenir intermittents, puis de finalement disparaître (figure 4F). Selon l'âge du patient et la concentration au site effecteur des agents hypnotiques, d'importantes différences doivent être détectées : avec des concentrations comparables au site effecteur, la puissance et la fréquence alpha déclinent toutes deux avec l'âge. ${ }^{19}$ En règle générale, la fréquence des fuseaux alpha ralentit habituellement avec des concentrations croissantes de l'agent anesthésique volatil au site effecteur. ${ }^{20}$
Anesthésie excessive

L'observation de l'EEG peropératoire peut également aider l'anesthésiologiste à éviter une possible surdose d'anesthésiques chez les patients sensibles. Bien que non spécifiques, les caractéristiques les plus évidentes d'une anesthésie excessive sur l'EEG sont les bouffées suppressives et la suppression persistante. Étant donné que la mesure de la concentration alvéolaire minimale (MAC - minimum alveolar concentration) était dérivée en fonction de l'absence de mouvement en réponse à une stimulation chirurgicale (chez $50 \%$ des patients), son dosage est, d'une certaine façon, basé sur l'effet anesthésique sur la moelle épinière, et pas nécessairement sur le cortex. ${ }^{21}$ C'est pourquoi l'introduction d'une mesure du MAC qui soit dépendante dans une certaine mesure de la suppression sur l'EEG pourrait constituer une mesure plus fiable de l'effet réel des anesthésiques volatils sur le cerveau. $^{22}$ Bien qu'une association entre la durée de suppression de l'EEG et un delirium subséquent ait été observée, ${ }^{23}$ laquelle pourrait être particulièrement pertinente chez les patients plus âgés ou plus fragiles, nous ne savons pas encore si une suppression prolongée de l'EEG est nocive. ${ }^{24}$ L'observation de l'EEG pourrait donner aux anesthésiologistes une idée de l'étendue à laquelle le cortex d'un patient en particulier est supprimé en réponse à une concentration anesthésique donnée. Par exemple, l'EEG peut être utilisé pour identifier les patients qui sont contre toute attente sensibles aux anesthésiques en raison d'une maladie systémique ou d'autres raisons.

\section{Divers effets de bruits connus à l'EEG}

Le signal de l'EEG reflète une activité électrique qui provient du cerveau ainsi que d'autres sources, soit dans le corps (par ex., les muscles cardiaques et squelettiques) ou à l'extérieur du corps (par ex. les matelas chauffants par convection), ou d'autres sources telles que la sueur ou le mouvement. La plupart des comptes rendus mentionnés plus haut font état des effets connus de diverses sources non neuronales sur l'EEG. En résumé, ces effets sont :

Les bruits parasites proviennent de toutes sortes d'équipements électriques dans l'environnement chirurgical. Par exemple, de l'électrocautérisation de la chirurgie (qui s'exprime sous forme de bruit à large bande sur toutes les bandes de fréquence) et de l'électrocardiogramme (ou ECG, où l'activité rythmique du cœur est facile à reconnaître). Des artéfacts sont également introduits lorsqu'on déplace les patients ou lorsque les électrodes de l'EEG sont manipulées (ce qui résulte en changements d'amplitude de l'EEG vastes et très soudains). Dans de telles situations, alors que le signal de l'EEG pourrait être temporairement déformé et impossible 
à interpréter, l'état d'hypnose du patient pourrait demeurer stable. La figure 5 présente un exemple du tracé laissé par une électrocautérisation dans l'EEG brut et sur le spectrogramme (sections A et B, respectivement).

L'activité musculaire est détectée électriquement en tant que signal d'électromyographie (EMG). L'activité de l'EMG dans l'EEG peut rendre le signal 'flou', étant donné que l'activité de l'EMG se situe habituellement dans la bande des hautes fréquences $(>20 \mathrm{~Hz})$. La figure 5 présente un exemple du tracé laissé par l'EMG dans l'EEG brut et sur le spectrogramme (sections $\mathrm{C}$ et $\mathrm{D}$, respectivement). Dans le spectrogramme ou la matrice de densité spectrale (DSA, pour density spectral array), l'activité musculaire se manifeste sous forme d'une puissance accrue sur plusieurs bandes de fréquence (c.-àd. il y a du bruit à large bande). Les agents d'anesthésie générale et les bloqueurs neuromusculaires réduisent l'activité musculaire, et diminuent donc la contamination du signal de l'EEG par l'EMG.

Chez certains patients, l'EEG pourrait également être de faible amplitude; alors que nous savons que l'amplitude de l'EEG diminue avec l'âge, la variance restante en matière d'amplitude pourrait être due à une neurodégénérescence ou à des facteurs génétiques. Chez de tels patients, on pourrait être tenté de penser que l'EEG est supprimé ou iso-électrique, mais il peut parfois être utile d'observer la façon dont le signal réagit à un changement de concentration de l'anesthésique pour déterminer si le signal est véritablement supprimé ou non. Il peut également être utile de réduire l'échelle d'amplitude (axe des ordonnées, y) pour la forme d'onde de l'EEG, qui est affichée en microvolts $(\mu \mathrm{V})$. Une échelle d'amplitude par défaut typique sera d'environ $25-50 \mu \mathrm{V}$ par $\mathrm{cm}$ sur l'écran d'affichage, dépendamment du moniteur. En réduisant l'échelle à environ $20 \mu \mathrm{V}$ par $\mathrm{cm}$, il est parfois possible de déterminer si des fuseaux alpha de plus petite amplitude et des oscillations d'ondes lentes sont présents.

Les anesthésiques non GABAergiques

L'effet des agents anesthésiques qui n'agissent pas par voie GABAergique, tels que le protoxyde d'azote et la kétamine, est bien connu et décrit dans certains des articles précédemment mentionnés. Lorsque ces agents sont utilisés, l'EEG frontal n'affichera pas les caractéristiques traditionnelles décrites plus haut. Avec ces deux agents, l'EEG comportera une composante de fréquence plus élevée, et très souvent une puissance moindre dans la bande alpha. L'ajout de perfusions de kétamine pendant une anesthésie générale à base de propofol ou d'agents volatils peut produire des ondes de fréquence plus élevée, telles que des ondes bêta, dans le tracé de l'EEG. Ces ondes surviennent en général en plus des tracés habituellement observés avec ces agents seuls. Dans de tels cas, un EEG qui affiche davantage de puissance de haute fréquence ne représentera probablement pas un état d'anesthésie plus léger, mais plutôt si les anesthésiques sont administrés comme adjuvants à un agent GABAergique, l'état hypnotique du patient sera probablement plus profond. La dexmédétomidine et d'autres agonistes alpha 2 tels que la clonidine produisent un EEG avec une onde lente dominante et des fuseaux intermittents. Lors de l'utilisation d'agonistes alpha 2, l'EEG présentera des caractéristiques communes au sommeil (typiquement les stades 2 et 3 ). ${ }^{17}$ En ligne avec cette observation, l'état sous sédation produit par la dexmédétomidine est beaucoup plus proche, dans certains aspects, de celui du sommeil que d'une anesthésie générale; alors que les aspects de l'EEG pourraient donner l'impression d'une anesthésie profonde avec des concentrations plus élevées de dexmédétomidine (c.-à-d. des oscillations lentes de vaste amplitude), un patient pourrait se réveiller abruptement de cet état en réaction à un stimulus chirurgical.

\section{Réactions non linéaires inattendues de l'EEG}

Étant donné les réactions «classiques» de l'EEG au niveau de la population (moyenne) à une augmentation de la concentration anesthésique décrites dans la section cidessus, on peut pardonner un anesthésiologiste de s'attendre à des changements graduels et linéaires sur l'EEG chez tous les patients passant par la salle d'opération. Toutefois, des réponses non linéaires de l'EEG à une augmentation ou une réduction des concentrations anesthésiques, comme un EEG non changeant ou changeant brusquement, sont relativement courantes au niveau individuel. Cette section a pour objectif d'offrir une mise à jour concernant deux phénomènes non linéaires clés sur un EEG auxquels un anesthésiologiste pourrait être confronté en situation clinique, soit (i) certaines réponses sur l'EEG à des stimuli douloureux et (ii) 'l'inertie neurale' (c.-à-d. la tendance du système nerveux central à résister aux transitions entre les états d'éveil).

Les stimuli douloureux et la réponse à l'EEG

À des concentrations d'agents anesthésiques modestes, le stimulus douloureux de la chirurgie ne provoquera pas de changement à l'EEG - si l'analgésie est adéquate - ou provoquera une dépolarisation thalamo-corticale. Dans cette situation, l'EEG pourrait afficher une perte d'ondes lentes et une augmentation des ondes de haute fréquence (bêta et gamma). L'augmentation des hautes fréquences est 
connue sous le nom 'd'éveil bêta' et ressemble au tracé d'éveil à la fin de l'anesthésie (figure 4). En revanche, un 'éveil delta' (aussi connu sous le nom 'd'éveil paradoxal') décrit une augmentation inattendue de l'amplitude des ondes lentes ou delta de l'EEG en réponse à une stimulation chirurgicale douloureuse - et tout particulièrement à une stimulation viscérale (figure 6). ${ }^{25}$ Cette réponse inattendue sur l'EEG a été rapportée pour la première fois au début des années $1990,{ }^{26}$ mais a peu été étudiée par la suite. ${ }^{27}$

Dans cette situation, le clinicien ne devrait pas réduire l'administration de l'agent anesthésique général (par ex. l'agent volatil ou le propofol) à moins que d'autres signes cliniques d'une anesthésie inadaptée soient présents, étant donné que cela pourrait entraîner une anesthésie inadéquate; plutôt, il a été suggéré qu'il serait plus approprié d'augmenter l'administration d'analgésiques. Il convient de noter qu'un éveil delta pourrait être le signe d'une activation antinociceptive endogène. Comme cela a été mentionné, ${ }^{28,29}$ certaines personnes peuvent également manifester d'autres expressions spécifiques d'un changement soudain d'EEG en réponse à une stimulation douloureuse, comme une perte soudaine de puissance dans la bande alpha - une 'perte de signal' alpha ${ }^{30}$ (figure 6). Les causes à l'origine de ces divers phénomènes demeurent inconnues.

\section{L'inertie neurale}

Alors que l'induction de l'anesthésie générale avec perte de conscience constitue une altération «active» de la fonction cérébrale induite par un médicament, le réveil de l'anesthésie et le retour de la conscience sont traditionnellement perçus comme des processus miroirs 'passifs', qui surviennent lors de l'élimination des agents anesthésiques du système nerveux central. Si cette conceptualisation était vraie, les concentrations anesthésiques au moment de la perte de conscience à l'induction et au moment du retour de la conscience au réveil seraient identiques. Toutefois, des études récentes sur des rongeurs et des mouches à fruit, ${ }^{31}$ ainsi que chez l'humain, ${ }^{32,33}$ rapportent des concentrations d'agent hypnotique (par ex. d'agent volatil) considérablement plus basses au retour de la conscience par rapport au moment de la perte de conscience. Il ne s'agit probablement pas seulement d'un facteur de confusion pharmacocinétique; plutôt, cela suggère l'implication de mécanismes différents dans les processus d'induction et de réveil. ${ }^{34}$ Toutes ces études suggèrent que l'hystérèse est davantage marquée dans les situations dans lesquelles les neuromodulateurs du réveil sont perturbés (par ex. vieillesse, narcolepsie, dropéridol, clonidine et agents antimuscariniques).
Les cliniciens doivent être prudents lorsqu'ils réduisent la concentration anesthésique (de l'agent volatil) à un seuil inférieur à la concentration requise pour rendre un patient inconscient en se fondant sur un tracé d'EEG affichant des caractéristiques évoquant une anesthésie générale (voir figure 7). La dynamique cérébrale est rarement monotone ou stable pendant divers états, y compris le sommeil et l'anesthésie générale. Ainsi, pendant le réveil de l'anesthésie générale (ou si l'anesthésiologiste tente intentionnellement de maintenir une anesthésie générale 'légère', juste au-dessus du seuil de l'éveil), on ne peut prédire exactement quand un patient en particulier passera d'un état inconscient à un état conscient et réactif. En outre, étant donné qu'il y a probablement hystérèse entre la concentration d'agent anesthésique hypnotique requise pour générer l'inconscience et la concentration à laquelle la conscience revient, lorsque la conscience revient (finalement), une importante augmentation de l'agent hypnotique pourrait être nécessaire pour restaurer un état d'inconscience. En d'autres termes, la $M_{\text {ACéveil }}$ est probablement une concentration plus basse de la $\mathrm{MAC}_{\mathrm{PdC}}$ (perte de conscience). Cela s'applique probablement tant aux patients individuels qu'à la population.

\section{Certains problèmes irrésolus, et l'avenir du monitorage cérébral par EEG}

La réactivité malgré un tracé d'EEG frontal d'anesthésie 'profonde'

Des recherches récentes utilisant la technique de l'avantbras isolé ont démontré que, dans certaines situations rares, un patient dont le tracé d'EEG frontal correspond à celui observé lors d'une anesthésie générale (c.-à-d. une onde lente importante et une activité de fuseaux alpha) pourrait tout de même - dans une certaine mesure - être conscient de, et connecté à, son environnement, comme le démontre une réponse à un ordre. ${ }^{35}$ Alors que ces événements sont relativement rares, et la pertinence clinique de tels états est encore sujette à discussion, ${ }^{36}$ ce phénomène suggère que les anesthésiques volatils pourraient causer un état dissocié plus prononcé qu'on ne le présumait. En termes plus philosophiques, il se pourrait que les anesthésiologistes ne soient pas toujours en train de réduire le niveau de conscience, mais plutôt que, parfois, ils ne font que dégrader le contenu de la conscience. ${ }^{37}$

Une réponse à cette observation est qu'alors que des ondes lentes et une activité de fuseaux alpha sont effectivement les mesures les plus pertinentes d'un niveau adéquat d'anesthésie, il est possible que nous regardions tout simplement au mauvais endroit. Le front est un endroit glabre qui fournit un accès à la fois facile et 
stable pour les électrodes de l'EEG, mais malgré le pragmatisme de ces observations, cela n'en fait pas nécessairement le meilleur endroit pour évaluer l'inconscience. Certains auteurs ont récemment proposé une «zone chaude » postérieure, où l'on pense que les neurones responsables de la conscience phénoménale sont situés. ${ }^{38}$ Mais la question reste ouverte.

Une deuxième réponse est que l'inconscience pourrait ne pas toujours être associée à une mesure EEG en particulier, prise d'un seul emplacement (bien qu'il n'existe aucun compte rendu à date portant sur des patients réactifs chez lesquels le tracé EEG montre des bouffées suppressives ou une suppression persistante), mais qu'elle serait plutôt dépendante d'une sorte de connectivité entre deux zones cérébrales ou plus. Par exemple, il a été démontré que les mesures de connectivité entre les zones frontale et pariétale baissaient lors de la perte de réactivité, et pas seulement avec le sévoflurane et le propofol, mais également avec l'agent non GABAergique qu'est la kétamine. ${ }^{39}$ Il existe cependant de nombreuses mesures différentes de la connectivité, et il n'a pas encore été déterminé de manière concluante laquelle était la meilleure. Ces observations remettent en question la perspective selon laquelle un EEG frontal consistant en une onde lente et une activité de fuseaux alpha constitue une expression authentique d'un système thalamo-cortical hyperpolarisé, et procure ainsi un corrélat fiable de l'inconscience. Il est clair que nous n'avons pas encore découvert les corrélats neuraux précis de l'inconscience. Ces mises en garde et problèmes irrésolus ne constituent pas pour autant une raison d'ignorer l'EEG chez les patients qui ont une relation classique de réaction à la concentration, ${ }^{40}$ mais clarifient plutôt l'objectif principal : toute mesure future de l'inconscience par EEG devra se fonder sur les corrélats neurobiologiques de l'inconscience. ${ }^{41}$

\section{Conclusion}

Notre compréhension de la neurobiologie de la conscience et des mécanismes sous-jacents à l'inconscience induite par l'anesthésie évolue. Dans le même temps, nous développons une compréhension plus nuancée de l'utilité de l'EEG en tant que moniteur pendant une anesthésie générale planifiée, ainsi qu'une appréciation de certaines des limites potentielles des applications actuelles de l'EEG.

Les approches courantes que nous utilisons traditionnellement, telles que la méthode de Fourier pour déconstruire la forme d'onde complexe de l'EEG en bandes de fréquence définies de façon arbitraire, peuvent être associées à une perte d'informations utiles. Par exemple, les relations entre différentes fréquences de l'EEG (les relations de fréquences croisées) ont probablement une pertinence neurobiologique. En outre, en se concentrant sur un seul canal d'EEG, on exclut l'évaluation des relations de l'EEG dans le cortex. Il existe probablement plus d'un mécanisme unitaire d'action anesthésique avec différents médicaments anesthésiques et combinaisons médicamenteuses. Il est également très peu probable qu'il existe une seule signature d'EEG qui s'applique à tous les patients de tous âges, indépendamment des combinaisons médicamenteuses et de l'intensité de la stimulation chirurgicale. C'est pourquoi il est important que les cliniciens en anesthésie qui intègrent le monitorage cérébral par EEG dans leur pratique comprennent tant ses forces que ses faiblesses. Il est peu surprenant que l'organe le plus complexe du corps s'avère être difficile à monitorer de façon précise pendant une anesthésie générale. Toutefois, si nous, anesthésiologistes, espérons offrir une médecine de précision à nos patients en salle d'opération et à l'unité de soins intensifs, le cerveau est la cible logique pour ce faire.

\section{Cas clinique}

Avant de subir une hémicolectomie droite par laparoscopie, un homme de 58 ans souffrant d'hypertension et d'obésité a reçu un bloc du plan transverse de l'abdomen (bloc TAP) combiné à une anesthésie générale par sévoflurane et fentanyl. L'induction de l'anesthésie se fait sans incident, mais avant l'incision et pendant l'insufflation de dioxyde de carbone dans le péritoine, le patient devient hypotendu, mais tout se résout grâce à votre traitement. Au cours des prochaines 90 minutes, le maintien de l'anesthésie est stable, sans changement majeur à l'hémodynamie ou à l'EEG, pendant que le chirurgien dissèque des adhérences abdominales. Après avoir accidentellement lacéré l'intestin, le chirurgien décide de procéder plutôt à une intervention ouverte et réalise une laparotomie. Vous remarquez un changement soudain sur l'EEG brut et la matrice de densité spectrale (DSA), dont vous vous chargez. La chirurgie progresse bien jusqu'à une perte sanguine sévère due à une déchirure de la veine cave inférieure. En raison de l'instabilité hémodynamique, vous réduisez l'administration d'anesthésique volatil à une concentration alvéolaire minimale (MAC) d'environ 0,4 pendant que vous réanimez le patient. Pendant la 
Tableau Nomenclature usuelle des bandes de fréquence dans l'EEG

\begin{tabular}{ll}
\hline Nom de la bande de fréquence & Bande de fréquence (en Hertz) \\
\hline Onde lente (parfois également appelée delta) & $0-1 \mathrm{~Hz}$ \\
Delta & $1-4 \mathrm{~Hz}$ (mais parfois $0-4 \mathrm{~Hz})$ \\
Thêta & $4-8 \mathrm{~Hz}$ \\
Alpha & $8-12 \mathrm{~Hz}$, également appelée mu, \\
Sigma & si enregistrée d'un cortex moteur \\
Bêta & $12-14 \mathrm{~Hz}$ souvent la bande de fréquence \\
& pour les fuseaux de sommeil pendant le sommeil physiologique \\
& Généralement 12-30 Hz (ou 14-30 Hz), mais aussi \\
Gamma & Bêta bas (<20 Hz) \\
\hline
\end{tabular}

Chez les patients démontrant un effet de réponse à la concentration typique sur leur EEG frontal,

l'EEG peut être utilisé pour guider la titration de l'anesthésique afin de prévenir un dosage insuffisant ou possiblement excessif de l'anesthésique. $\mathrm{EEG}=$ électroencéphalogramme

réanimation du patient, les changements à l'EEG ne sont pas remarqués. Vous êtes content quand le patient redevient enfin stable, et vous reconnaissez de hautes ondes delta pendant l'irrigation de l'abdomen juste avant la fin de l'opération.

\section{Directives pour compléter le module de développement professionnel continu (DPC):}

\section{Lisez cet article et les références en gras.}

Allez à: https://www.cas.ca/fr/education-fr/developpementprofessionnel-continu afin d'accéder à notre système de gestion de l'apprentissage, enregistrez-vous et choisissez le module actuel Une introduction mise à jour du monitorage cérébral par encéphalogramme pour une anesthésie générale planifiée). Votre nom d'utilisateur correspond à l'adresse électronique enregistrée dans le répertoire des membres et votre mot de passe correspond à votre identifiant de la Société canadienne des anesthésiologistes. Ce module est agréé pour trois ans. Vous pouvez retrouver la période exacte d'agrément sur le site internet de la SCA et dans le système de gestion de l'apprentissage.

6. Répondez aux questions à choix multiples portant sur le cas clinique.

7. Une fois que vous aurez saisi toutes vos réponses, vous aurez accès aux explications d'experts pour tous les choix possibles.

8. Les participants peuvent déclarer jusqu'à quatre heures de DPC en vertu de la section 3 du Programme de MDC du Collège royal des médecins et chirurgiens du Canada.
Disclosures None.

Funding statement Darren Hight is funded by the BangerterRhyner Foundation (Basel) and by a CTU-Research-Grant of the Insel Gruppe AG, Inselspital, University Hospital of Bern.

Editorial responsibility This submission was handled by Dr. Adriaan Van Rensburg, CPD Editor, Canadian Journal of Anesthesia.

Déclaration Aucune.

Déclaration de financement Darren Hight est financé par la Fondation Bangerter-Rhyner (Bâle, Suisse) et par une Bourse de recherche de l'Unité des essais cliniques (CTU) du Groupe Insel AG, Hôpital de l'Île, Hôpital universitaire de Berne, Suisse.

Responsabilité éditoriale Cet article a été traité par Dr Adriaan Van Rensburg, rédacteur des DPC, Journal canadien d'anesthésie.

\section{References}

1. Gibbs FA, Gibbs EL, Lennox WG. Effect on the electroencephalogram of certain drugs which influence nervous activity. Arch Intern Med (Chic) 1937; 60: 154-66.

2. Alkire MT, Hudetz AG, Tononi G. Consciousness and anesthesia. Science 2008; 322: 876-80.

3. Brown EN, Lydic R, Schiff ND. General anesthesia, sleep, and coma. N Engl J Med 2010; 363: 2638-50.

4. Steriade M, McCormick DA, Sejnowski TJ. Thalamocortical oscillations in the sleeping and aroused brain. Science 1993; 262: 679-85.

5. Amzica $F$, Steriade $M$. Integration of low-frequency sleep oscillations in corticothalamic networks. Acta Neurobiol Exp (Wars) 2000; 60: 229-45

6. Lewis LD, Voigts J, Flores FJ, et al. Thalamic reticular nucleus induces fast and local modulation of arousal state. Elife 2015; DOI: https://doi.org/10.7554/eLife.08760.

7. Goldberger AL, Amaral LA, Glass L, et al. PhysioBank, PhysioToolkit, and PhysioNet: components of a new research 
resource for complex physiologic signals. Circulation 2000; 101: e215-20.

8. McCarthy MM, Brown EN, Kopell N. Potential network mechanisms mediating electroencephalographic beta rhythm changes during propofol-induced paradoxical excitation. J Neurosci 2008; 28: 13488-504.

9. Purdon PL, Pierce ET, Mukamel EA, et al. Electroencephalogram signatures of loss and recovery of consciousness from propofol. Proc Natl Acad Sci USA 2013; 110: E1142-51.

10. Gugino LD, Chabot RJ, Prichep LS, John ER, Formanek V, Aglio $L S$. Quantitative EEG changes associated with loss and return of consciousness in healthy adult volunteers anaesthetized with propofol or sevoflurane. Br J Anaesth 2001; 87: 421-8.

11. Rampil IJ. A primer for EEG signal processing in anesthesia. Anesthesiology 1998; 89: 980-1002.

12. Jameson LC, Sloan TB. Using EEG to monitor anesthesia drug effects during surgery. J Clin Monit Comput 2006; 20: 445-72.

13. Brown EN, Purdon PL, Van Dort CJ. General anesthesia and altered states of arousal: a systems neuroscience analysis. Annu Rev Neurosci 2011; 34: 601-28.

14. Bennett C, Voss LJ, Barnard JP, Sleigh JW. Practical use of the raw electroencephalogram waveform during general anesthesia: the art and science. Anesth Analg 2009; 109: 539-50.

15. Jagadeesan $N$, Wolfson $M$, Chen $Y$, Willingham M, Avidan MS. Brain monitoring during general anesthesia. Trends Anaesth Crit Care 2013; 3: 13-8.

16. Marchant $N$, Sanders $R$, Sleigh JW, et al. How electroencephalography serves the anesthesiologist. Clin EEG Neurosci 2014; 45: 22-32.

17. Purdon PL, Sampson A, Pavone KJ, Brown EN. Clinical electroencephalography for anesthesiologists: part I: background and basic signatures. Anesthesiology 2015; 123: 937-60.

18. Pandit JJ, Andrade J, Bogod DG, et al. 5th National Audit Project (NAP5) on accidental awareness during general anaesthesia: summary of main findings and risk factors. Br J Anaesth 2014; 113: 549-59.

19. Purdon PL, Pavone KJ, Akeju O, et al. The ageing brain: agedependent changes in the electroencephalogram during propofol and sevofluranegeneral anaesthesia. $\mathrm{Br} \mathrm{J}$ Anaesth 2015; 115(Suppl 1): i46-57.

20. Hight D, Voss LJ, García PS, Sleigh J. Changes in alpha frequency and power of the electroencephalogram during volatile-based general anesthesia. Front Syst Neurosci 2017; DOI: https://doi.org/10.3389/fnsys.2017.00036.

21. Antognini JF, Schwartz K. Exaggerated anesthetic requirements in the preferentially anesthetized brain. Anesthesiology 1993; 79: 1244-9.

22. Pilge S, Jordan D, Kreuzer M, Kochs EF, Schneider G. Burst suppression-MAC and burst suppression-CP50 as measures of cerebral effects of anaesthetics. Br J Anaesth 2014; 112: 1067-74.

23. Fritz BA, Maybrier HR, Avidan MS. Intraoperative electroencephalogram suppression at lower volatile anaesthetic concentrations predicts postoperative delirium occurring in the intensive care unit. Br J Anaesth 2018; 121: 241-8.

24. Wildes TS, Mickle AM, Ben Abdallah A, et al. Effect of electroencephalography-guided anesthetic administration on postoperative delirium among older adults undergoing major surgery: the ENGAGES randomized clinical trial. JAMA 2019; DOI: https://doi.org/10.1001/jama.2018.22005.

25. Bischoff P, Kochs E, Haferkorn D, Schulte am Esch J. Intraoperative EEG changes in relation to the surgical procedure during isoflurane-nitrous oxide anesthesia: hysterectomy versus mastectomy. J Clin Anesth 1996; 8: 36-43.
26. Kochs E, Bischoff P, Pichlmeier U, Schulte am Esch J. Surgical stimulation induces changes in brain electrical activity during isoflurane/nitrous oxide anesthesia: a topographic electroencephalographic analysis. Anesthesiology 1994; 80: 1026-34.

27. Morimoto $Y$, Matsumoto A, Koizumi Y, Gohara T, Sakabe T, Hagihira $S$. Changes in the bispectral index during intraabdominal irrigation in patients anesthetized with nitrous oxide and sevoflurane. Anesth Analg 2005; 100: 1370-4.

28. MacKay EC, Sleigh JW, Voss LJ, Barnard JP. Episodic waveforms in the electroeneephalogram during general anaesthesia : a study of patterns of response to noxious stimuli. Anaesth Intensive Care 2010; 38: 102-12.

29. Sleigh JW, Leslie K, Voss L. The effect of skin incision on the electroencephalogram during general anesthesia maintained with propofol or desflurane. J Clin Monit Comput 2010; 24: 307-18.

30. Hight DF, Gaskell AL, Kreuzer M, Voss LJ, García PS, Sleigh $J W$. Transient electroencephalographic alpha power loss during maintenance of general anaesthesia. Br J Anaesth 2019; 122: 635-42.

31. Friedman EB, Sun Y, Moore JT, et al. A conserved behavioral state barrier impedes transitions between anesthetic-induced unconsciousness and wakefulness: evidence for neural inertia. PLoS One 2010; DOI: https://doi.org/10.1371/journal.pone. 0011903.

32. Warnaby CE, Sleigh JW, Hight D, Jbabdi S, Tracey I. Investigation of slow-wave activity saturation during surgical anesthesia reveals a signature of neural inertia in humans. Anesthesiology 2017; 127: 645-57.

33. Kuizenga MH, Colin PJ, Reyntjens KM, et al. Test of neural inertia in humans during general anaesthesia. Br J Anaesth 2018; 120: 525-36.

34. Kelz MB, Sun Y, Chen J, et al. An essential role for orexins in emergence from general anesthesia. Proc Natl Acad Sci USA 2008; 105: 1309-14.

35. Gaskell AL, Hight DF, Winders J, et al. Frontal alpha-delta EEG does not preclude volitional response during anaesthesia: prospective cohort study of the isolated forearm technique. Br J Anaesth 2017; 119: 664-73.

36. Pandit JJ, Russell IF, Wang M. Interpretations of responses using the isolated forearm technique in general anaesthesia: a debate. Br J Anaesth 2015; 115(Suppl 1): i32-45.

37. Mashour GA, Hudetz AG. Bottom-up and top-down mechanisms of general anesthetics modulate different dimensions of consciousness. Front Neural Circuits 2017; DOI: https://doi.org/ 10.3389/fncir.2017.00044.

38. Boly M, Massimini M, Tsuchiya N, Postle BR, Koch C, Tononi G. Are the neural correlates of consciousness in the front or in the back of the cerebral cortex? Clinical and neuroimaging evidence. J Neurosci 2017; 37: 9603-13.

39. Lee U, Ku S, Noh G, Baek S, Choi B, Mashour GA. Disruption of frontal-parietal communication by ketamine, propofol, and sevoflurane. Anesthesiology 2013; 118: 1264-75.

40. Mashour GA, Avidan MS. Black swans: challenging the relationship of anaesthetic-induced unconsciousness and electroencephalographic oscillations in the frontal cortex. Br J Anaesth 2017; 119: 563-5.

41. Mashour GA, Hudetz AG. Neural correlates of unconsciousness in large-scale brain networks. Trends Neurosci 2018; 41: 150-60.

Publisher's Note Springer Nature remains neutral with regard to jurisdictional claims in published maps and institutional affiliations. 